MUSICA THEORICA 2020, V. 5.2

SCIENTIFIC ARTICLE

Data do recebimento: 07/05/2021

Data da aprovação final: 10/06/2021

\title{
Gestos Conclusivos na Sinfonia n. 8 (1950) de Heitor Villa-Lobos
}

\author{
Conclusive Gestures in Symphony no. 8 (1950) by Heitor Villa-Lobos
}

\author{
Adailton Sergio Pupia \\ Universidade Federal do Paraná
}

\begin{abstract}
Resumo: A Sinfonia n. 8 (1950) de Heitor Villa-Lobos (1887-1959) é marcada pela estreita relação do compositor com os Estados Unidos, assim como a busca por uma linguagem musical universal. Pertencente a quarta fase criativa, essa sinfonia é caracterizada pelo retorno aos gêneros musicais do passado e pelo distanciamento do nacionalismo. Constatamos a presença de diversos diálogos com estruturas, técnicas e procedimentos herdados de estilos e de compositores precursores. Dentre os múltiplos processos criativos empregados por Villa-Lobos, destacamos um procedimento alusivo à linguagem harmônica cadencial, sendo um artifício típico da escrita villalobiana. Investigamos dez tipos de gestos conclusivos presentes na Sinfonia $n$. 8, ocorrentes nos finais de seções e de movimentos, sendo designados como: finalização em mônadas; finalização em díades; finalização em acorde pentatônico; finalização wagneriana; finalização por acorde Tristão; finalização por motivo Tristão; finalização varèsiana; finalização em quartas; finalização diatônica; e finalização cromática.
\end{abstract}

Palavras-chave: Sinfonia n. 8. Heitor Villa-Lobos. Análise musical. Gestos conclusivos.

\begin{abstract}
The Symphony no. 8 (1950) by Heitor Villa-Lobos (1887-1959) is marked by the composer's close relationship with the United States, as well as the search for a universal musical language. Belonging to the fourth creative phase, this symphony is characterized by the return to the musical genres of the past and the distance from nationalism. We found the presence of several dialogues with structures, techniques and procedures inherited from styles and previous composers. Among the multiple creative processes employed by VillaLobos, we highlight a procedure alluding to cadential harmonic language, being a typical artifice of Villalobian writing. We investigated ten types of conclusive gestures present in Symphony no. 8, occurring at the end of sections and movements, being designated as: cadence in monad; cadence in dyads; cadence in pentatonic chord; Wagnerian cadence; cadence by Tristan chord; cadence by Tristan motif; Varèsian cadence; cadence in fourths; diatonic cadence; and chromatic cadence.
\end{abstract}

Keywords: Symphony no. 8. Heitor Villa-Lobos. Musical analysis. Conclusive gestures. 
MUSICA THEORICA Revista da Associação Brasileira de Teoria e Análise Musical 2020,

v. 5, n. 2, p. 226-258 - Journal of the Brazilian Society for Music

Theory and Analysis@ TeMA 2020 - ISSN 2525-5541

\section{Introdução}

Heitor Villa-Lobos (1887-1959) compôs ao longo de sua vida doze sinfonias ${ }^{1}$, sendo as cinco primeiras escritas no período de 1916 até 1920 . Após um hiato de 25 anos, o compositor retomou o ciclo compondo mais sete sinfonias no período de 1944 a $1957^{2}$. Pela prolífera quantidade de sinfonias e, nas palavras do próprio Villa-Lobos ${ }^{3}$, verificamos a importância deste tipo de composição em seu repertório. É conveniente recordar que o arquétipo da sinfonia já foi considerado fundamental para a consagração de um compositor. A sinfonia se tornou o principal veículo de propagação da música orquestral no final do século XVIII e, a partir de Ludwig van Beethoven, passou a ser considerada a mais alta e exaltada forma musical. Para muitos compositores, a elaboração de uma sinfonia foi um fardo pesado de se carregar. Tomamos como exemplo Johannes Brahms, que vivenciou a pressão do legado sinfônico deixado por Beethoven ${ }^{4}$.

As seis últimas sinfonias villalobianas foram compostas em um momento no qual o compositor obtinha um prestígio considerável na Europa e nos Estados Unidos. Dedicado à sua carreira internacional, constantemente recebia encomenda de novas obras e era frequentemente convidado a conduzir orquestras no exterior.

Supostamente, a Sinfonia n. 8, composta no Rio de Janeiro em 1950, oferece uma mudança de direção no ciclo das sinfonias. Ela é a primeira que não contém

\footnotetext{
${ }^{1}$ De acordo com o catálogo de obras editado pelo Museu Villa-Lobos, Villa-Lobos, sua obra, a quinta sinfonia, composta em 1920, é dada como perdida (Museu Villa-Lobos 2009, p. 44).

${ }^{2}$ Pertinente a essa lacuna deixada entre as primeiras e as últimas sinfonias, Salles (2020) oferece uma interessante investigação acerca da datação da Sinfonia n. 2, composta em 1917, estreada apenas em 1944. O autor sugere que, entre a datação original e a estreia, alterações ou revisões foram incorporadas nesta sinfonia, indicando uma possível reelaboração ou mesmo a concepção desta sinfonia durante a década de 1930. Embasado nas argumentações de Salles (2020), podemos considerar inconsistências nas datações originais de algumas sinfonias, questionando se a lacuna de vinte e cinco anos presente no ciclo realmente ocorreu.

${ }^{3}$ Segue um excerto da palestra proferida em Paris em 1958, onde o compositor considera a sinfonia uma composição musical superior: "o que é uma sinfonia, em meu ponto de vista, no ponto de vista de todas as pessoas que escrevem sinfonias? É uma música pela música. Música superior, música intelectual, não é música para ser assobiada por todo mundo. Bem, quando há uma sinfonia, se alguém tenta empregar efeitos especiais, de tipo exótico, folclore ou algo parecido, eu não acho correto chamá-la de sinfonia" (Guérios 2009, p. 167).

${ }^{4}$ David Brodbeck no livro Brahms: Sinfonia n. 1 de 2017, discute profundamente a angústia de Brahms em suceder o legado de Beethoven, em especial após a sua nona sinfonia.
} 
um programa extramusical ${ }^{5}$. Villa-Lobos a desenvolveu por meio de procedimentos composicionais já estabelecidos e recorrentes na música ocidental, inserindo sutilmente elementos da música popular brasileira, não evidenciando um caráter nacionalista. Estreada em Nova Iorque em 1955 pela Orquestra da Filadélfia no Carnegie Hall, sob a regência do próprio Villa-Lobos, foi dedicada ao crítico musical norte americano Olin Downes, que era engajado na descoberta e na militância pela música de grandes compositores de fora da Europa Central e dos Estados Unidos, como o finlandês Jean Sibelius e o brasileiro Heitor Villa-Lobos. Downes divulgou estes dois compositores nos Estados Unidos, ajudando a torná-los menos "exóticos" aos olhos e ouvidos do grande público ${ }^{6}$. Influente, Downes era crítico musical há trinta anos do New York Times, diretor musical da Feira de Nova Iorque e integrante da comissão musical do Departamento de Estado.

Olin Downes apoiou Villa-Lobos além da imprensa. Em uma das diversas cartas $^{7}$ trocadas com Villa-Lobos, o crítico norte americano diz ter encontrado Charles Seeger ${ }^{8}$ em uma reunião em Washington, na qual reforçou a articulação

\footnotetext{
${ }^{5}$ As cinco primeiras sinfonias possuem subtítulos: Sinfonia n. 1 "O Imprevisto" (1916); Sinfonia $n$. 2 "Ascenção" (1917); Sinfonia n. 3 "A Guerra" (1919); Sinfonia n. 4 "Vitória" (1919); Sinfonia n. 5 “A Paz" (1920). Já na Sinfonia n. 6 (1944), o tema principal é baseado na linha melódica extraída pelo autor do contorno das montanhas do Brasil, por meio do processo por ele criado e denominado "Melodia das Montanhas". A Sinfonia n. 7 (1945), subintitulada de "Odisseia da Paz" ou de "Odisseia de uma Raça" foi escrita para um concurso em Detroit (EUA) e, conforme exigido pelo regulamento, foi submetida de forma anônima, sob o pseudônimo A. Caramuru (Museu Villa-Lobos 2009, p. 41-45).

${ }^{6}$ Carol Hess (2013) aponta que Olin Downes talvez tenha sido o primeiro crítico estadunidense a comparar as obras de Villa-Lobos com a música de Bach (Hess 2013, p. 125). O retorno a Bach foi um sucesso em 1930 nos Estados Unidos, sendo apropriado pela crítica como "símbolo do universalismo cultural, da união dos povos e da ideia de transcendência coletiva" (Rodrigues 2019, p. 212). Downes conclamava os leitores a apreciar a música de Villa-Lobos como uma ponte entre o classicismo de Bach e o elemento nacional. As Bachianas Brasileiras (1930-1945), ao que tudo indica, marcam o início da fase "universal" de Villa-Lobos.

${ }^{7}$ Entre as diversas cartas trocadas por Villa-Lobos e Downes, destacamos aqui os dois convites oficiais (1943 e 1947) realizados por Villa-Lobos. Nestas cartas, o compositor brasileiro oferece estadia no Brasil custeada pelo governo federal por alguns meses a Downes, porém ambos os convites não se concretizaram.

${ }^{8}$ Seeger chefiou a divisão de música da União Pan-Americana no auge da Política da Boa Vizinhança e agenciou músicos, musicólogos e professores em torno de uma política cultural voltada para o continente americano (Rodrigues 2019, p. 200).
} 
pela ida de Villa-Lobos aos Estados Unidos'. Na última carta enviada a VillaLobos, em 15 de maio de 1954, Downes acusa o recebimento da partitura da Sinfonia n. 8. Downes faleceu no ano seguinte (Rodrigues 2019, p. 211-212).

Composta em 1945, aproximadamente um ano após sua visita aos Estados Unidos, a precursora Sinfonia n. 7, sem dedicatória, foi escrita para um concurso de composição promovido pela Orquestra Sinfônica de Detroit. A sinfonia não obteve nenhuma premiação e estreou em 1949, com a Orquestra Sinfônica de Londres, regida pelo compositor. Apesar dos infortúnios da Sinfonia n. 7 (1945), tão sofisticada e estimada pelo compositor como uma de suas melhores obras, ela não obteve o sucesso almejado, contudo, serviu como um termômetro de receptividade, em especial da crítica e do público dos Estados Unidos.

Com isso, podemos supor que Villa-Lobos não desejava comprometer ou arriscar sua próxima empreitada sinfônica e a oitava sinfonia é a confirmação dessa consciência. A Sinfonia $n .8$ foi estreada nos Estados Unidos, sendo a primeira sinfonia do compositor a ter sua première em território estadunidense. Para que isso ocorresse, alguns aspectos da sua linguagem musical foram ajustados ou, melhor dizendo, universalizados, em uma possível tentativa de se enquadrar ao perfil americano.

De acordo com nossas investigações, Villa-Lobos concebe o universalismo $^{10}$ na Sinfonia $n .8$ por meio do abandono da excêntrica instrumentação; da renúncia de uma concepção formal mais livre; da pouca

\footnotetext{
${ }^{9}$ A ida de Villa-Lobos aos Estados Unidos se concretizou apenas no final de 1944.

${ }^{10}$ Uma interessante reflexão sobre o universalismo na música é oferecida por Arthur Farwell no The International Cyclopedia of Music and Musicians de 1985. O autor elenca cinco tipos de referências que definem as verdadeiras músicas universalistas. Segundo Farwell (1985), essas composições podem conter: 1 . A música de pessoas que não têm nacionalidade específica, ou seja, culturas primitivas; 2 . A música de camponeses de países com uma identidade cultural estabelecida; 3. A música composta por meio de citações de canções folclóricas; 4. A música composta não baseada em citações, mas sutilmente evocativa de um determinado povo; 5 . A música de compositores que transfiguram e embelezam a alma nacional, em seu aspecto mais exaltado. Esta última categoria, segundo o autor, inclui compositores como Joseph Haydn, Wolfgang Amadeus Mozart e Ludwig van Beethoven, compositores dos quais absorveram a essência da sua canção nacional (Farwell 1985, p. 1488-1489). Refletindo sobre estas cinco características universalistas oferecidas por Farwell (1985), observamos pontos em comum entre a concepção de universalidade e o conceito de intertextualidade, onde os compositores se apropriam de elementos da música do passado de caráter nacional ou folclórico, transfigurando em novas obras musicais.
} 
recorrência de exotismo nas texturas, orquestrações e ambientações; do desuso da música programática; da ausência abundante da temática folclórica e popular; e do controle de procedimentos criativos intuitivos ou mesmo exploratórios. Entretanto, Villa-Lobos não ignora integralmente estes aspectos mencionados, ele os oferece de forma mais ponderada, dialogando com a música do passado de forma consciente, por meio dos aspectos estruturais, estilísticos e simétricos, aludindo aos procedimentos composicionais que possuem certo establishment (Pupia 2021, p. 185).

Dividida em quatro movimentos, a Sinfonia $n .8$ dialoga com quatro modelos formais. O primeiro movimento, o Andante, é inspirado em uma estrutura seccional, sendo comumente empregada na música do século XIX e XX, como em poemas sinfônicos ou em obras de caráter pós-tonal. O Lento (Assai), segundo movimento, faz alusão ao grande ternário, sistemicamente empregado por diferentes compositores, em especial por compositores do classicismo. $\mathrm{O}$ Allegretto Scherzando, terceiro movimento, possui um caráter jocoso, característico da forma scherzo, que pode estar diretamente ligado à música de Ludwig van Beethoven. E o quarto movimento, o Allegro (Justo), oferece o importante arquétipo da forma sonata, presente em obras musicais dos mais variados compositores. Villa-Lobos alude à forma sonata do tipo monotemática, fartamente presente na música de Joseph Haydn. Assim como em alguns compositores neoclássicos, Villa-Lobos faz referência às estruturas tradicionais de forma bastante particular, estabelecendo sua personalidade (Pupia 2021, p. 185-186).

Dentre os diversos procedimentos criativos empregados por Villa-Lobos na oitava sinfonia, como os variados tipos de simetrias, citações temáticas, referências estilísticas, reaproveitamento de materiais e alusões aos aspectos formais, destacamos um interessante procedimento que está relacionado ao fechamento de seções ou de movimentos. Neste estudo, substituímos o termo "cadência" por "finalização", com o intuito de melhorar a compreensão. Diferente da "cadência", a "finalização" não está associada a progressões tonais específicas, como cadências autênticas perfeitas, plagais, de engano, interrompida, etc. $\mathrm{O}$ termo está relacionado com os procedimentos de encerramento, sejam estes elementos gestuais, texturais, timbrísticos, rítmicos, melódicos, etc., onde Villa-Lobos manipula, ou substitui o arquétipo funcional 
tonal, utilizando outros tipos de simetrias, muitas vezes aludindo aos procedimentos advindos de compositores precursores.

\section{Gestos conclusivos na música villalobiana}

Fernandez (1946) e Salles (2018) investigam os processos harmônicos empregados por Villa-Lobos tendo como ponto de partida o estudo das suas cadências conclusivas, observando de que forma o compositor organiza a harmonia, sendo inspirado pela estrutura formal do classicismo. De acordo com Fernandez (1946), Villa-Lobos foi o primeiro compositor brasileiro a romper as normas harmônicas tradicionais, oferecendo em suas composições uma grande instabilidade tonal, com tendências para bitonalidade, politonalidade e, em certos momentos, para a atonalidade, porém, sempre de forma espontânea (Fernandez 1946, p. 285).

Salles (2009), em seus estudos prévios aos procedimentos de encerramento de seções ou de movimentos na obra de Villa-Lobos, observou duas fórmulas recorrentes, designando-as de cadências do tipo wagneriana e varèsiana (Salles 2009, p. 144). Estes dois tipos de gestos conclusivos são frequentemente observados no repertório villalobiano, como no poema sinfônico Uirapuru (1917), cadência do tipo wagneriana e no Choros n. 8 (1925), cadência do tipo varèsiana. Em seu recente livro: Os Quartetos de Cordas de Villa-Lobos: Forma e Função, Salles (2018) oferece um inventário das cadências utilizadas por VillaLobos nos dezessete quartetos de cordas. Além da já mencionada finalização do tipo varèsiana, o autor observa finalizações em oitavas (mônadas, também chamadas pelo autor de finalização haydniana), díades (duas notas), tricordes, tetracordes, pentacordes, hexacordes e septacordes.

Para ilustrar os tipos de acordes frequentemente utilizados nas cadências villalobianas, apresento o quadro elaborado por Salles (2018), onde constam os acordes e as coleções de classe de altura $^{11}$, em forma prima, mais empregadas por Villa-Lobos nos dezessete quartetos de cordas.

\footnotetext{
${ }^{11}$ Para melhor compreensão, consultar a tabela de formas primárias e vetores de classes de notas de Allen Forte. The Structure of Atonal Music, 1973, p. 179-181.
} 


\begin{tabular}{|c|c|c|}
\hline Tipo & \multicolumn{2}{|l|}{ Elemento } \\
\hline \multirow{2}{*}{ Tricordes } & Tríades tonais & $\begin{array}{l}\text { 3-11 (maior ou menor) (037) } \\
\text { 3-12 (aumentada) }(048) \\
\text { 3-10 (diminuta) }(036)\end{array}$ \\
\hline & \multicolumn{2}{|c|}{$\begin{array}{l}\text { 3-3 (maior-menor) (014) } \\
\text { 3-7 (subconjunto da pentatônica, 5-35) (025) } \\
\text { 3-9 (superposição de quintas) }(027)\end{array}$} \\
\hline Tetracordes & \multicolumn{2}{|c|}{$\begin{array}{l}\text { 4-8 (quartas justas por semitom) }(0156) \\
\text { 4-17 (maior/menor) }(0347): 3-11+3-3 \\
\text { 4-20 (maior com } 7 \mathrm{M})(0158) \\
\text { 4-21 (tons inteiros) }(0246) \\
\text { 4-23 (superposição } 4 \mathrm{~J} / 5 \mathrm{~J})(0257) \\
\text { 4-25 (tons inteiros) }(0268) \\
\text { 4-26 (menor com sétima menor) }(0358)(\text { Ex.: } \mathrm{C}+\mathrm{Am}=\mathrm{Am} 7)\end{array}$} \\
\hline Pentacordes & \multicolumn{2}{|c|}{$\begin{array}{l}\text { 5-22 “acorde maior varèsiano" }(01478)(\mathrm{Ex} .: \mathrm{C}+\mathrm{C} \# \mathrm{~m}) \\
\text { 5-33 (subconjunto tons inteiros) }(02468) \\
\text { 5-35 (pentatônica) }(02479)\end{array}$} \\
\hline Hexacordes & \multicolumn{2}{|c|}{$\begin{array}{l}\text { 6-z29 (023679) }(\text { Ex.: Cm + D) } \\
\text { 6-32 (quintas) }(024579)(\text { Ex.: C + Dm) } \\
6-35 \text { (coleção de inteiros) }(02468 T)\end{array}$} \\
\hline Septacordes & \multicolumn{2}{|c|}{$\begin{array}{l}\text { 7-34 (coleção acústica) }(013468 \mathrm{~T}) \\
\text { 7-35 (coleção diatônica) }(013568 \mathrm{~T})\end{array}$} \\
\hline
\end{tabular}

Tabela 1: Acordes e coleções de classe de altura (em sua forma prima) mais usados por Villa-Lobos (Salles 2018, p. 172).

Salles (2018) também oferece um levantamento estatístico dos tipos de cadências finais presentes em todos os movimentos dos quartetos de cordas de Villa-Lobos. A maior recorrência é da cadência em mônadas, empregada vinte e oito vezes ${ }^{12}$. Em segundo lugar, o autor observa a presença da tríade menor com sétima menor $(\mathrm{FN}=4-26)$, ocorrendo oito vezes. Em terceiro lugar, com sete ocorrências, estão as tríades perfeitas $(\mathrm{FN}=3-11)$.

Na Sinfonia $n$. 8 de Villa-Lobos, investigamos a presença de dez tipos de finalizações, denominadas de: finalização em mônadas; finalização em díades; finalização em acorde pentatônico; finalização wagneriana; finalização por acorde Tristão; finalização por motivo Tristão; finalização varèsiana; finalização em quartas; finalização diatônica; e finalização cromática.

\footnotetext{
${ }^{12}$ Interessante observar que mais da metade destas cadências em mônadas, presentes nos quartetos de cordas de Villa-Lobos, ocorrem na nota Dó, estando presente em doze dos dezessete quartetos, ocorrendo dezesseis vezes.
} 
MUSICA THEORICA Revista da Associação Brasileira de Teoria e Análise Musical 2020,

v. 5, n. 2, p. 226-258 - Journal of the Brazilian Society for Music

\section{Finalização em mônadas}

A finalização em mônada (uníssono ou oitavas) é recorrente na Sinfonia $n$. 8 , sendo empregada quatro vezes. Este recurso é bastante comum nas obras tardias de Villa-Lobos. Duarte (2009) observa, curiosamente, esse procedimento adotado pelo compositor, questionando qual seria a intenção de Villa-Lobos no emprego de tal artifício.

\footnotetext{
“Apesar de mestre na harmonia tradicional e também na contemporânea, é muito curioso observar o fato de que, na maioria das composições de VillaLobos, incluindo movimentos de sinfonias, concertos e suítes, o uníssono está presente em cerca de $80 \%$ a $90 \%$ dos finais. Muitíssimas vezes, este uníssono é com a nota dó. Vale como curiosidade, mas paira no ar a pergunta, ainda sem resposta: por quê?" (Duarte 2009, p. 87-88).
}

Salles (2018) também compartilha dessa curiosidade em relação às finalizações em mônadas, mencionando que esse procedimento incide após passagens densas, de caráter não tonal, chegando a soar de forma abrupta e improvável, sendo uma assinatura musical do compositor (Salles 2018, p. 156). Ainda, segundo o autor, este tipo de finalização aparenta ser uma alusão aos procedimentos de encerramento de Joseph Haydn, observando que grande parte dos dez primeiros quartetos do compositor austríaco apresenta este tipo de arquétipo conclusivo. Este procedimento também é recorrente nas sinfonias de Haydn, em especial em suas primeiras sinfonias.

Na Sinfonia n. 8 de Villa-Lobos encontramos a finalização em mônadas nos encerramentos dos quatro movimentos. No primeiro movimento, o Andante, essa finalização ocorre no compasso 191, último compasso do movimento, após a apresentação e suspensão de um acorde de Láb aumentado com sétima maior, o movimento é finalizado na nota Dó em oitavas. No Lento (Assai), segundo movimento, esse procedimento acontece nos compassos 61 e 62, onde, após o acorde de dominante, Fá maior com sétima menor com dissonâncias agregadas, o movimento conclui em oitavas na nota Sib. No terceiro movimento, o Allegretto Scherzando, após uma pequena condução melódica ascendente por graus conjuntos, observamos a nota Sol em oitavas nos dois últimos compassos do movimento, compassos 141 e 142. Por fim, no último movimento, o Allegro (Justo), após um paralelismo em quartas superpostas com o pedal da nota Sol, a finalização em mônada ocorre nos compassos 210 e 211, novamente na nota Dó em oitavas. A figura 1 ilustra as quatro recorrências das finalizações em mônadas. 

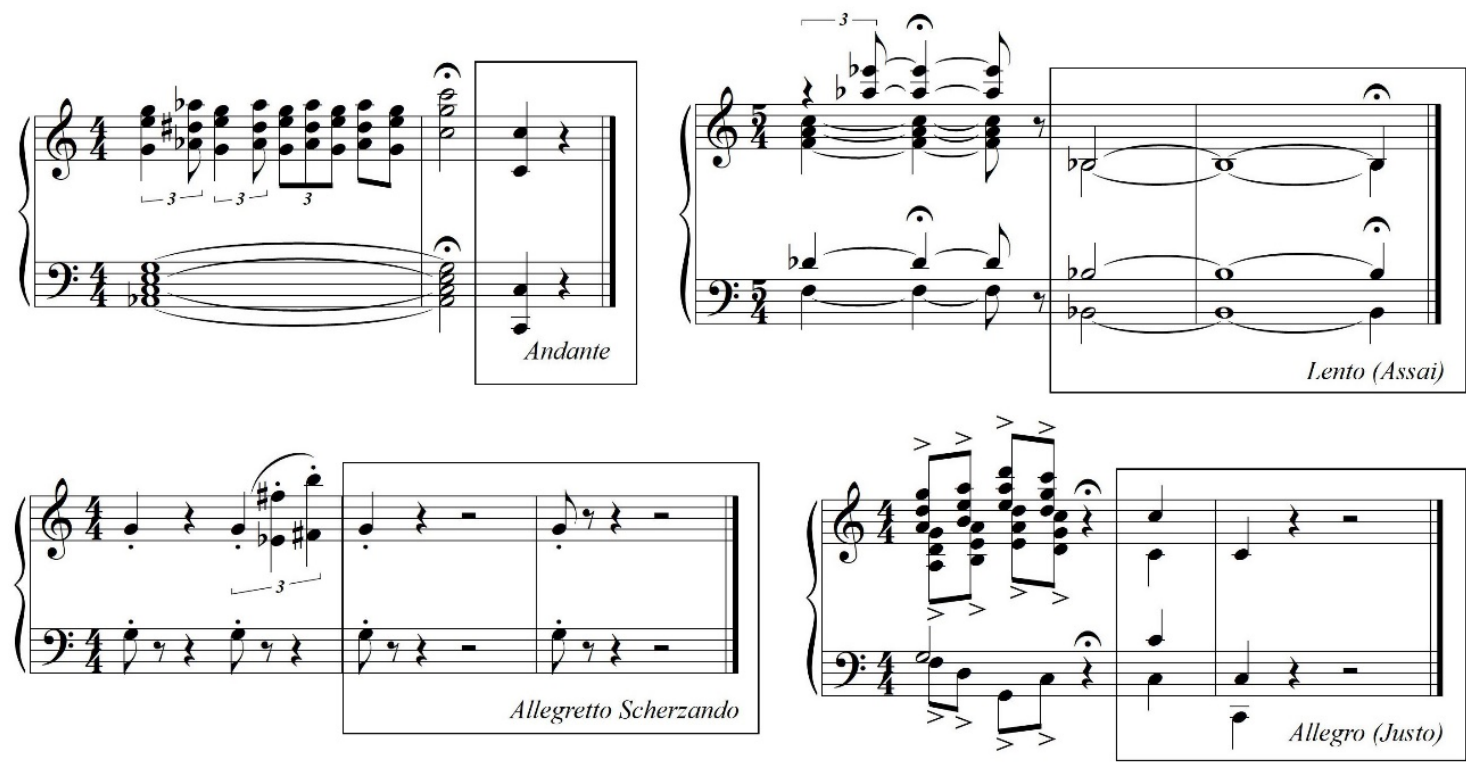

Figura 1: Finalizações em oitavas (mônadas) ocorrentes na Sinfonia n. 8 de Heitor VillaLobos. Redução.

Corroborando o levantamento estatístico oferecido por Duarte (2009) e Salles (2018), das quatro ocorrências da finalização em mônadas nesta sinfonia, duas delas ocorrem na nota Dó, sendo no final do primeiro e do quarto movimento.

Este tipo de finalização é um traço característico na música villalobiana, conforme menciona Salles (2018), podendo ser considerada uma propriedade estilística do compositor. Apenas para ilustrar, além dos já mencionados quartetos de cordas, também observamos essa finalização em mônadas no Choros n. 7 (1924), Choros n. 9 (1929), Momô Precoce (1929), Uirapurú (1917), Kankikis (1916) e no Sexteto Místico (1917). Nas sinfonias, observamos este gesto conclusivo em mônadas na conclusão dos seguintes movimentos: Allegro Assai Moderato, Scherzo e Allegro Con Brio da Sinfonia n. 1 (1916); Allegro non Troppo, Allegretto Scherzando e Allegro da Sinfonia n. 2 (1917); Allegro Impectuoso e Andantino da Sinfonia n. 4 (1919); Allegro non Troppo e Lento da Sinfonia n. 6 (1944); Allegro Vivace e Scherzo da Sinfonia n. 7 (1945); Scherzo e Allegro Giusto da Sinfonia n. 9 (1952); Lento da Sinfonia n. 10 (1952); Largo e Molto Allegro da Sinfonia n. 11 (1955); Allegro non Troppo, Adagio, Scherzo e Molto Allegro da Sinfonia n. 12 (1957). 


\section{Finalização em díades}

As díades foram empregadas com características cadenciais inicialmente na música medieval. Também chamada de bicorde, a primeira menção teórica é apresentada no tratado Micrologus (1026) de Guido D’Arezzo (Corrêa 2012, p. 33). No Andante, primeiro movimento da Sinfonia $n$. 8, observamos um gesto conclusivo por meio de uma díade no final da primeira seção. No compasso 38, o clarone, os fagotes, o contrafagote, o trombone, a tuba e os tímpanos, expõem as notas Mi e Si simultaneamente, uma díade, oferecendo um possível acorde de $\mathrm{Mi}$, sem definir o modo, conforme ilustra a figura 2.

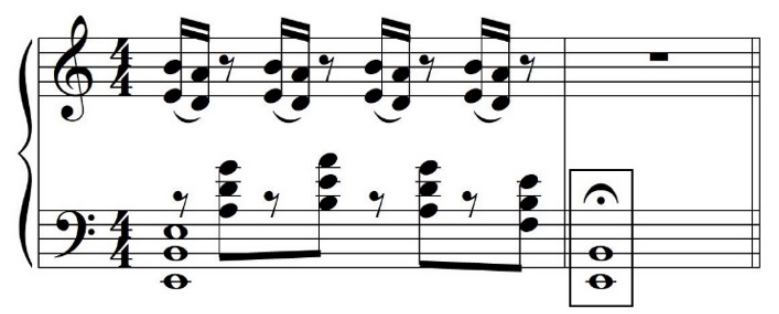

Figura 2: Finalização em díades no Andante da Sinfonia n. 8 de Heitor Villa-Lobos. Redução. Compassos 37 e 38.

Observamos um procedimento similar na transição para o Piu Mosso do Lento (Assai), em que a grande maioria dos instrumentos suspende a nota Lá, que é sobreposta pela nota Réb, uma quinta aumentada abaixo de Lá, sendo executada pela terceira e quarta trompas no final compasso 34, caracterizando uma finalização em díade, conforme exibe a figura 3.

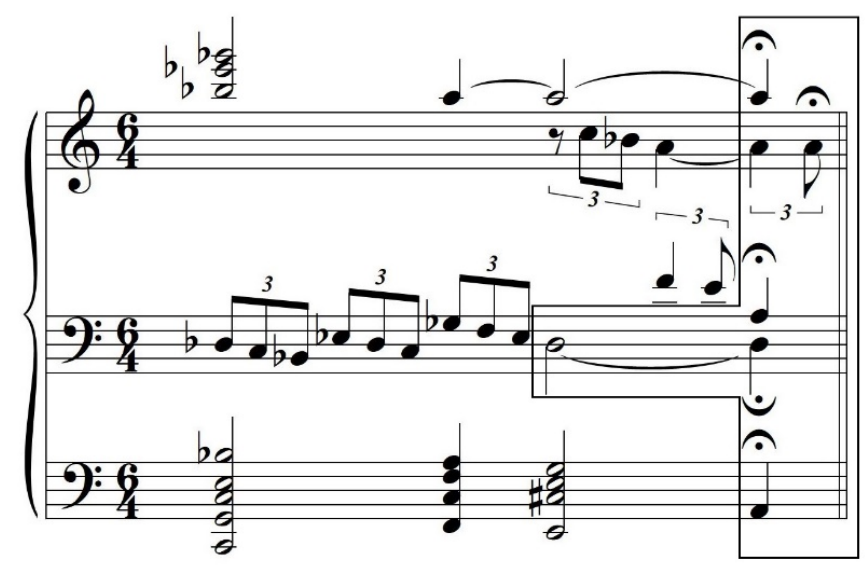

Figura 3: Finalização em díades no Lento (Assai) da Sinfonia n. 8 de Heitor Villa-Lobos. Redução. Compasso 34. 
Este tipo de procedimento em díades não é tão recorrente na obra villalobiana, se comparado com as finalizações em mônadas. Nos dezessete quartetos de cordas, segundo as análises de Salles (2018), as finalizações em díades ocorrem apenas em três momentos, sendo duas vezes dispostas em intervalos de quinta justa e uma vez disposta em intervalo de sexta menor.

\section{Finalização em acorde pentatônico}

Outro tipo de finalização recorrente na música de Villa-Lobos é o uso das coleções pentatônicas. Segundo Coelho de Souza (2017), as coleções pentatônicas estão presentes em boa parte do repertório villalobiano, em especial, em obras de caráter infantil; de representação primitiva; de menção a cultura do Oriente, possivelmente advindas da música de Debussy; e pela particularidade da técnica instrumental, como é o caso do instrumento violão, que oferece a afinação ${ }^{13} \mathrm{em}$ intervalos de quintas. Outro procedimento ocorrente na música de Villa-Lobos consiste na mescla, sobreposição ou alternância entre coleções diatônicas e pentatônicas (Coelho de Souza 2017, p. 391).

Salles (2018) aponta para a presença de seis acordes pentatônicos nos procedimentos de finalização dos quartetos de cordas villalobianos. $\mathrm{O}$ acorde pentatônico $(\mathrm{FN}=5-35)$ também está presente no Lento (Assai) da Sinfonia n. 8, no compasso 48, de forma conclusiva e suspensiva, preparando o excerto seguinte, construído em uma sequência de quintas ${ }^{14}$. O acorde pentatônico $5 \times 5^{15}$ em Réb é apresentado pelas madeiras. A figura 4 ilustra esse acorde. As notas Dó e Solb não foram consideradas como parte constituinte deste acorde pentatônico, sendo bordaduras das notas Réb e Fá.

\footnotetext{
${ }^{13}$ Coleção pentatônica simétrica, sendo Mi (primeira e sexta cordas), Sol (terceira corda), Lá (quinta corda), Si (segunda corda) e Ré (quarta corda).

${ }^{14}$ A sequência de quintas é constituída por uma progressão de acordes nos quais a fundamental de cada acorde é disposta sequencialmente em intervalos de quintas justas. Essas sequências de tríades ou tétrades em intervalos de quintas são comuns na música tonal ocidental, em especial na música barroca.

15 Descrevemos os acordes compostos pela sobreposição de quartas ou quintas utilizando a nomenclatura oferecida por Kostka (2006). Exemplo: “5x5 em Réb”, que significa 5 classes de notas dispostas em intervalos de quintas, sendo iniciada na nota Réb (Réb-Láb-Mib-Sib-Fá).
} 
MUSICA THEORICA Revista da Associação Brasileira de Teoria e Análise Musical 2020, v. 5, n. 2, p. 226-258 - Journal of the Brazilian Society for Music

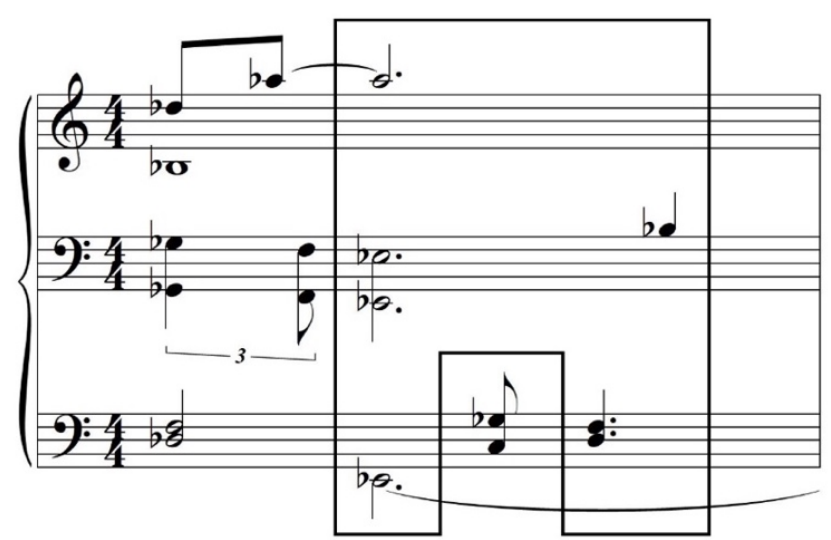

Figura 4: Finalização no acorde pentatônico no Lento (Assai) da Sinfonia n. 8 de Heitor Villa-Lobos. Redução. Compasso 48.

No compasso 88 do Allegretto Scherzando também constatamos a presença do acorde pentatônico. O acorde 5x5 em Láb é oferecido pelas cordas, tendo sua resolução em outro acorde pentatônico, o 5x5 em Sib, presente no compasso 89, conforme apresenta a figura 5 e 6.

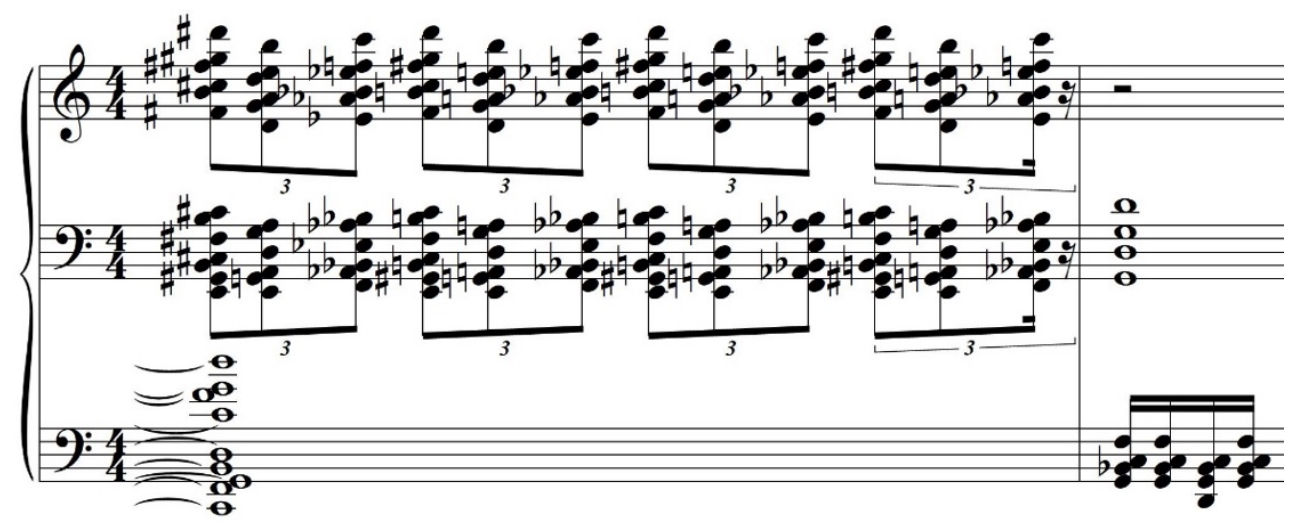

Figura 5: Finalização no acorde pentatônico no Allegretto Scherzando da Sinfonia n. 8 de Heitor Villa-Lobos. Redução. Compasso 88 e 89.

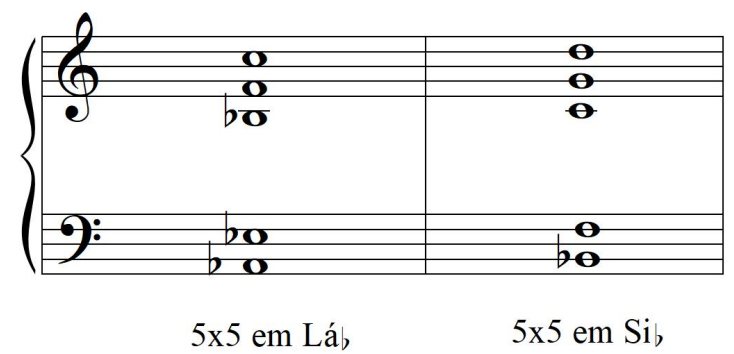

Figura 6: Acordes pentatônicos no Allegretto Scherzando da Sinfonia n. 8 de Heitor VillaLobos. Redução. Compasso 88 e 89. 


\section{Finalização wagneriana}

Diferente dos procedimentos de finalização já apresentados, investigamos também a presença de gestos conclusivos que possivelmente aludem a obras específicas, como é o caso do Prelúdio da ópera Tristão e Isolda (1859). Sem dúvida, Richard Wagner exerceu grande influência na obra de Villa-Lobos e de diversos compositores do final do século XIX. No Brasil, a influência wagneriana incidiu pelo filtro da música francesa, por meio de compositores reconhecidamente cultores da música do compositor alemão, como César Franck, Vincent d'Indy e Camille Saint-Säens. De acordo com Salles (2004), mesmo em Debussy é possível observar a influência wagneriana ${ }^{16}$, ainda que sua música seja considerada oposta à de Wagner (Salles 2004, p. 267).

Segundo Dudeque (2016), durante a década de 1880, Alberto Nepomuceno e Leopoldo Miguéz, principais compositores brasileiros da época, exibiam certas preferências estéticas germânicas, demarcadas pelo apreço à obra de Richard Wagner, influenciando diretamente suas composições e o trabalho no Instituto Nacional de Música, onde Villa-Lobos foi aluno por um período (Dudeque 2016, p. 14). Villa-Lobos se encontrava em um ambiente onde a música de Wagner era reverenciada. Ademais, o tratado de composição de d'Indy ${ }^{17}$, do qual Villa-Lobos supostamente conheceu profundamente, oferece várias referências à ópera Tristão e Isolda, assim como outras obras de Wagner.

Salles (2009) comenta que o maior empréstimo que Villa-Lobos fez da música de Wagner está no "campo da orquestração e na apresentação de pequenos fragmentos temáticos à maneira dos leitmotios wagnerianos, presentes em vários de seus poemas sinfônicos" (Salles 2009, p. 24). Villa-Lobos, assim como tantos compositores, não ficou imune às várias análises e discussões em torno das inovações harmônicas do Prelúdio da ópera Tristão e Isolda, cujos acordes iniciais se tornaram uma espécie de arquétipo harmônico (Salles 2009, p. 28).

\footnotetext{
${ }^{16}$ Inclusive citando parodicamente Wagner por meio do acorde Tristão em Golliwogg's Cake Walk da suíte Children's Corner (1908) (Salles 2004, p. 267).

${ }^{17}$ Resultado de sua atividade pedagógica na Schola Cantorum de Paris, o Cours de Composition Musicale de Vincent d'Indy ultrapassou os muros da instituição. O primeiro livro é datado de 1903. A publicação do segundo livro, primeira parte, é datada de 1909 e a segunda parte foi publicada em 1933.
} 


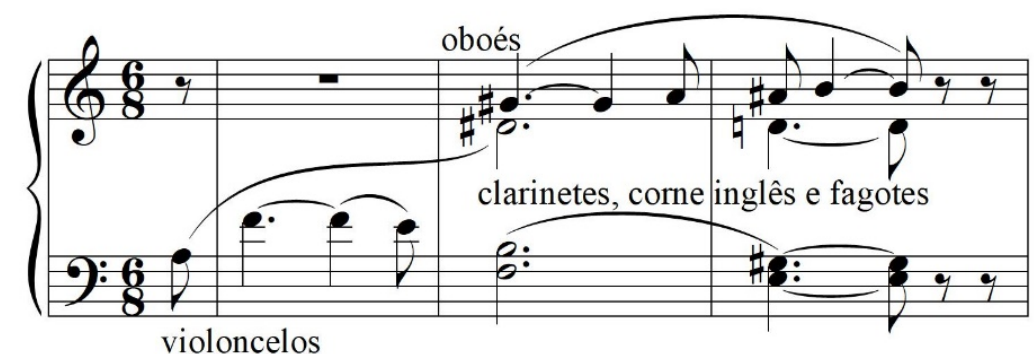

Figura 7: Redução dos compassos iniciais do Prelúdio da ópera Tristão e Isolda de Richard Wagner. Compassos 1 a 3.

Investigamos a presença de três gestos conclusivos empregados na Sinfonia $n .8$ que possivelmente são inspirados no Prelúdio de Tristão e Isolda. O primeiro deles, a finalização wagneriana, nomeada por Salles (2009) como cadência wagneriana, é derivado diretamente do Prelúdio da ópera do compositor alemão, em que a oscilação harmônica da obra conclui em oitavas paralelas na região grave, "como se esse final, harmonicamente "puro", nos advertisse quanto à impossibilidade de concluir satisfatoriamente todo o processo cromático desdobrado até aquele instante" (Salles 2009, p. 144). Essa conclusão insatisfatória ocorre principalmente pela não resolução do acorde de Sol maior, possivelmente a dominante de Dó menor, de acordo com a progressão estabelecida no excerto, seguido pela suavização da textura e da orquestração, culminando em movimentos paralelos de oitavas, realizadas pelos contrabaixos e violoncelos. O último compasso do excerto apresentado por Wagner também possui a função de conexão com a primeira cena da ópera. O acorde de Sol maior não é concluído na tônica implícita, Dó menor, sendo a nota Sol utilizada como uma nota em comum para a introdução da nova tonalidade na primeira cena da ópera, em Sol menor. A figura 8 ilustra o excerto.

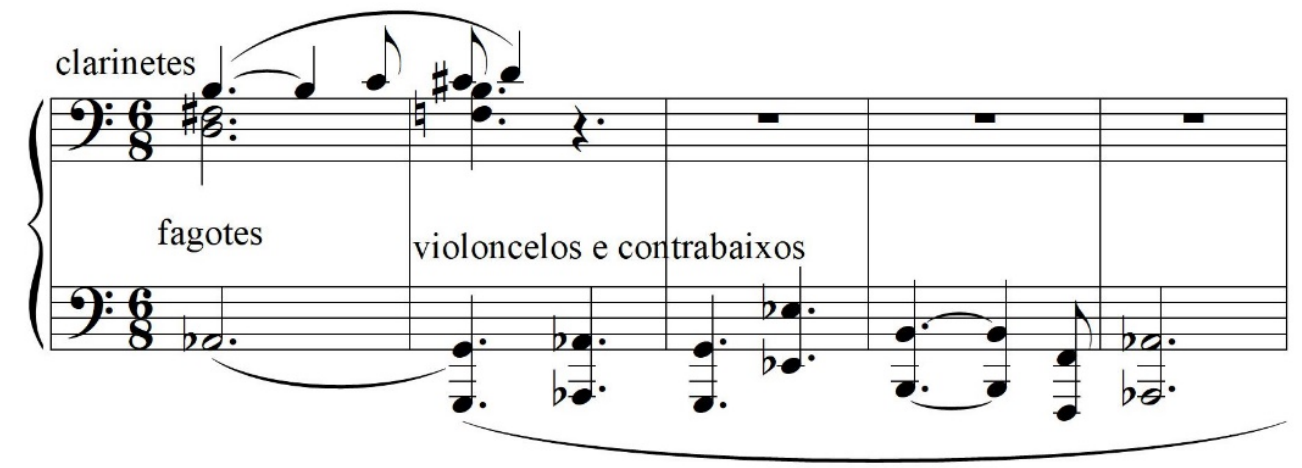




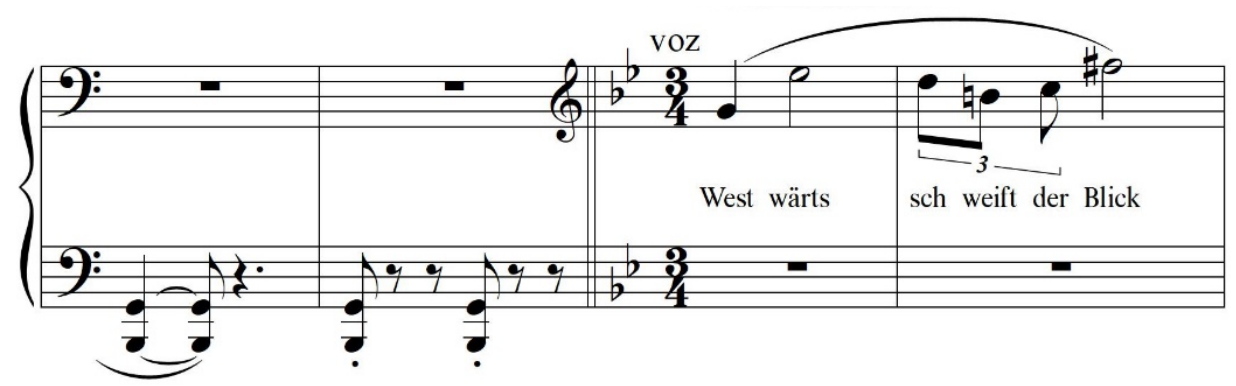

Figura 8: Final do Prelúdio de Tristão e Isolda de Richard Wagner. Redução. Compassos 105 a 113.

Notamos um procedimento similar na seção de encerramento do Allegro para o Piи Mosso do primeiro movimento da Sinfonia n.8 de Villa-Lobos. A textura e a orquestração oferecidas nos compassos 101 a 105 são análogas ao processo empregado por Wagner. Neste excerto, observamos a presença das oitavas paralelas realizadas pelos contrabaixos, a liquidação da textura e da orquestração densa para uma textura tênue, abrandando as ressonâncias apresentadas pelos acordes antecessores. Outro procedimento equivalente ao de Wagner também é observado na conexão entre estas duas seções. A nota Ré, apresentada no compasso 104, tem a função de dominante, sendo resolvida na nota Sol do compasso seguinte. Essa finalização realizada pelos contrabaixos, de Ré para Sol, é sobreposta pelo início do tema principal transformado, presente no Piu Mosso, iniciado na nota Ré, harmonizada por acordes quartais, 4×4 em Ré. A nota Ré neste excerto possui características de conexão das seções por nota em comum, similar ao procedimento utilizado por Wagner. Essas alusões podem ser observadas na redução oferecida na figura 9.

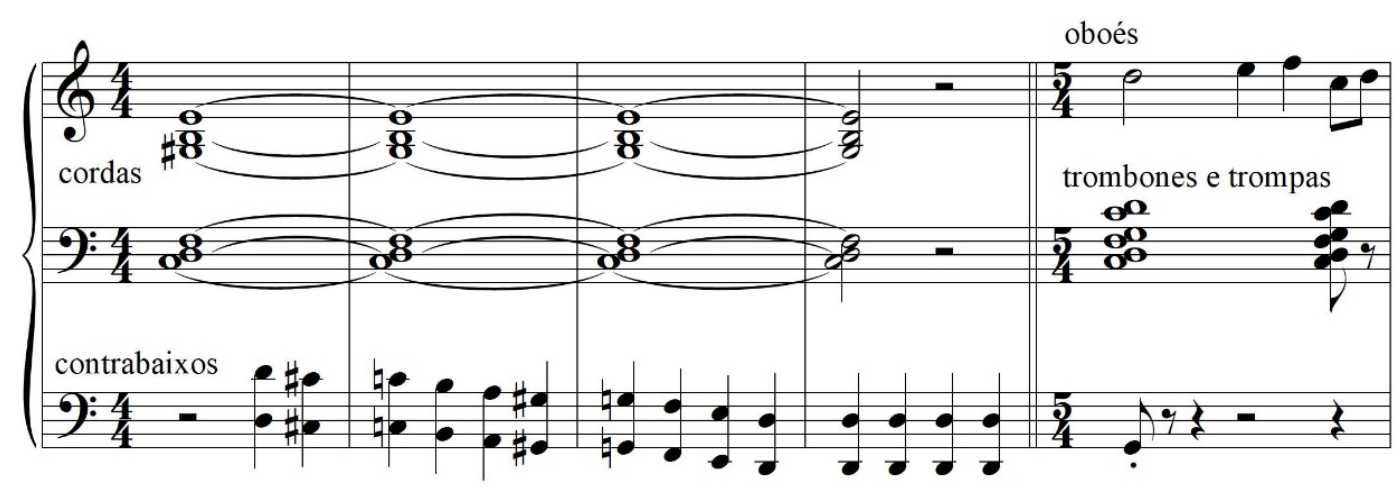

Figura 9: Finalização wagneriana no Andante da Sinfonia n. 8 de Heitor Villa-Lobos. Redução. Compassos 101 a 105. 
MUSICA THEORICA Revista da Associação Brasileira de Teoria e Análise Musical 2020,

v. 5, n. 2, p. 226-258 - Journal of the Brazilian Society for Music

\section{Finalização por acorde Tristão}

Outra recorrência encontrada na música de Villa-Lobos advinda da influência wagneriana é o emprego do acorde Tristão, sendo observada em diversas obras do compositor, como no poema sinfônico Uirapuru (1917), no Prelúdio n. 3 (1940) para violão e no Choros n. 8 (1925) (Salles 2004, p. 5). Esse acorde se tornou um arquétipo harmônico, sendo analisado por diversos teóricos.

O francês Jacques Chailley (1962) considera este acorde não como um verdadeiro acorde, mas, sim, uma antecipação por meio de duas apojaturas e de duas notas invertidas do acorde de dominante. A nota Fá é considerada pelo autor como uma apojatura da nota Mi. A nota Ré\# é considerada como uma apojatura da nota Réł e a nota Lá é caracterizada como uma nota de passagem. Finalmente, as apojaturas são resolvidas e a nota Lá\#, considerada como uma nota de passagem, resolve na nota Si. Já a nota Sol\#, troca de voz, movendo-se uma oitava abaixo (Nattiez 1984, p. 248). A figura 10 apresenta a ilustração oferecida por Chailley (1962).

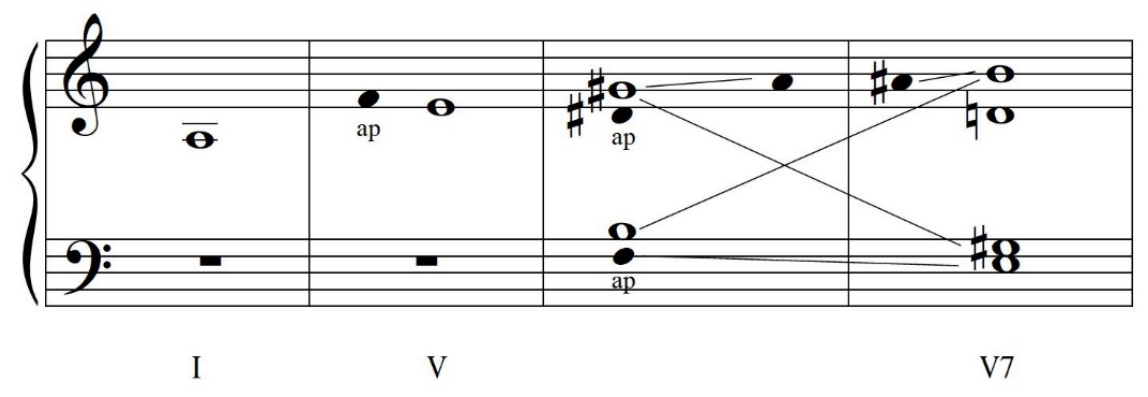

Figura 10: Ilustração apresentada por Chailley (1962) (Nattiez 1984, p. 248).

Arnold Schoenberg traça duas considerações sobre o acorde em diferentes momentos de sua vida. Em $1911^{18}$, Schoenberg considera o acorde Tristão como um acorde errante na tonalidade de Lá menor e, em $1948^{19}$, considera este acorde sendo o segundo grau com sétima da tonalidade de Lá menor.

Existem muitas divergências entre os teóricos quanto à estrutura deste acorde e sua função tonal. Muitos consideram a nota Sol\# como uma nota integrante do acorde, outros autores sugerem que a nota Sol\# é apenas uma

\footnotetext{
${ }^{18}$ Schoenberg, Arnold. Harmonielehre. Universal-edition, Leipzig, Wien, 1911.

${ }^{19}$ Schoenberg, Arnold. Structural Functions of Harmony. Norton, New York, 1948.
} 
apojatura para a nota Lá. Nattiez (1984) apresenta uma tabela onde constam diversas observações de teóricos categorizando o acorde Tristão. Nesta tabela ${ }^{20}$, podemos observar detalhadamente as variáveis presentes nas análises deste acorde.

Na figura 11 observamos o acorde Tristão na sua formação original, como apresentado no segundo compasso do Prelúdio da ópera Tristão e Isolda.

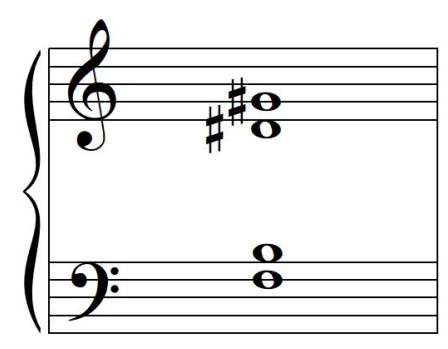

Figura 11: Acorde de Tristão.

Se alterarmos a disposição das notas exibidas pelo acorde Tristão de forma enarmônica, sendo a nota Láb correspondente à nota Sol\#, a nota Mib correspondente à nota Ré\# e a nota Dób correspondente à nota Si, evidenciamos a formação do acorde de Fá meio diminuto, constituído por uma tríade diminuta com sétima menor, conforme ilustra a figura 12.

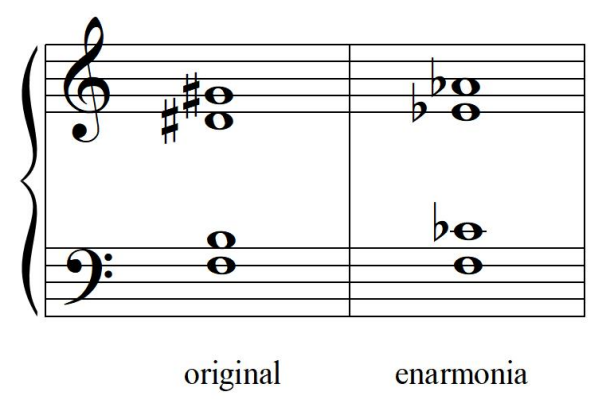

Figura 12: Acorde Tristão em sua forma original e enarmônica.

No compasso 18 do Lento (Assai), segundo movimento da Sinfonia n. 8, constatamos a presença do acorde de Si meio diminuto, ilustrado na figura 13 , empregado de forma conclusiva, possivelmente aludindo ao acorde Tristão.

\footnotetext{
${ }^{20}$ Tabela disponível em: Nattiez, Jean-Jacques. Verbete “Harmonia”. Enciclopédia Einaudi (volume 3). Lisboa: Imprensa Nacional, 1984.
} 
Apenas a existência do acorde meio diminuto não justificaria sua relação com o acorde Tristão. Entretanto, como estamos constatando, o Lento (Assai) oferece uma série de alusões aos procedimentos empregados no Prelúdio de Tristão e Isolda, auxiliando na legitimação da interpretação desse acorde meio diminuto de forma análoga ao acorde exposto por Richard Wagner. Salles (2004) menciona que Villa-Lobos utilizou o acorde Tristão no poema sinfônico Uirapuru (1917) como um comentário musical, em um procedimento sofisticado de paródia ou pastiche, "onde o acorde não é tratado como matéria harmônica, mas como "objeto-sonoro"" (Salles 2004, p. 148). Podemos supor que, neste excerto da Sinfonia $n$. 8, Villa-Lobos emprega o acorde Tristão de forma similar ao empregado em Uirapuru, constituindo em um "objeto sonoro".

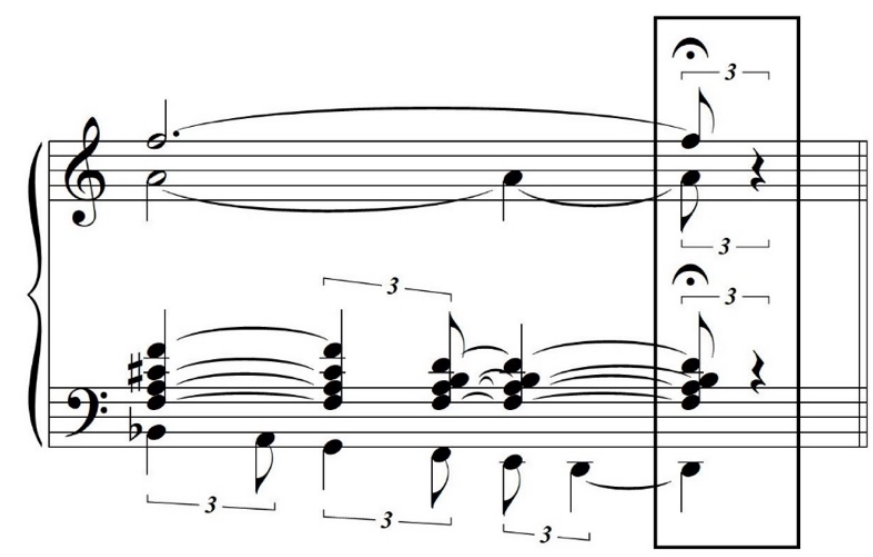

Figura 13: Finalização em acorde Tristão no Lento (Assai) da Sinfonia n. 8 de Heitor Villa-Lobos. Redução. Compasso 18.

\section{Finalização por motivo Tristão}

Outro tipo de finalização inspirada na música wagneriana pode ser relacionado ao contorno melódico presente no arquétipo inicial do Prelúdio de Tristão e Isolda, sendo nomeado por Piedade (2017a) como motivo Tristão. De grande importância, este motivo é bastante discutido e empregado comumente em diversas obras (Piedade 2017a, p. 282). Essa melodia é caracterizada por uma sexta menor ascendente, seguida por um cromatismo descendente, conforme ilustra a figura 14 . 


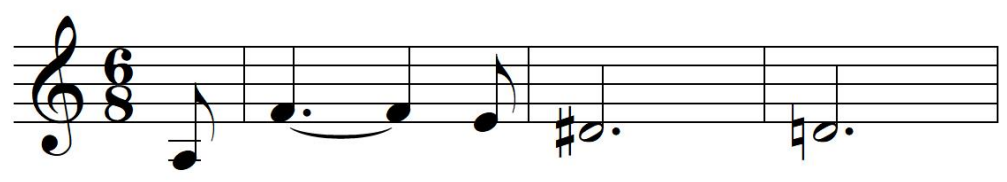

Figura 14: Motivo Tristão de Richard Wagner.

Este tipo de gesto melódico é recorrente na música villalobiana ${ }^{21}$, sendo geralmente empregado em momentos nos quais há uma sobreposição de procedimentos inspirados no prelúdio wagneriano. Não podemos afirmar que apenas a presença de um intervalo de sexta menor ascendente remeta ao prelúdio wagneriano, pois necessitamos de mais elementos que corroborem essa alusão.

Segundo Piedade (2017b), a alusão ao tema Tristão é baseada no contexto da obra como um todo, sendo pela admiração de Villa-Lobos pela música de Wagner; pela simbologia historicamente construída do prelúdio wagneriano; pela reação aos acordes iniciais desta ópera pela comunidade de musicólogos e compositores; e, sobretudo, pela forma que Villa-Lobos insere essas citações, comprometendo ou contaminando todas as sextas menores ascendentes subsequentes, ocasionando essa analogia ao prelúdio wagneriano (Piedade 2017b, p. 213).

No Lento (Assai) da Sinfonia n. 8, destacamos, anteriormente, alguns elementos que aludem ao Prelúdio da ópera Tristão e Isolda. Contribuindo com essas associações, entre os compassos 2 e 3, observamos o intervalo de sexta menor ascendente, idêntico ao prelúdio wagneriano, ambos iniciados na nota Lá2, seguidos pela nota Fá3. A terceira nota, o Mi, é substituída por Villa-Lobos pela nota Solb, que mantém a relação cromática, porém de forma ascendente, seguida por um salto descendente de sétima menor, diferente do cromatismo apresentado por Wagner. A figura 15 ilustra o motivo Tristão villalobiano.

\footnotetext{
${ }^{21}$ A presença do motivo Tristão também foi investigada no primeiro movimento da Bachianas Brasileiras n. 2. Vide: Adailton Sergio Pupia, Intertextualidade na Bachianas Brasileiras n. 2 de Heitor Villa-Lobos, 2017, UFPR (dissertação de mestrado).
} 


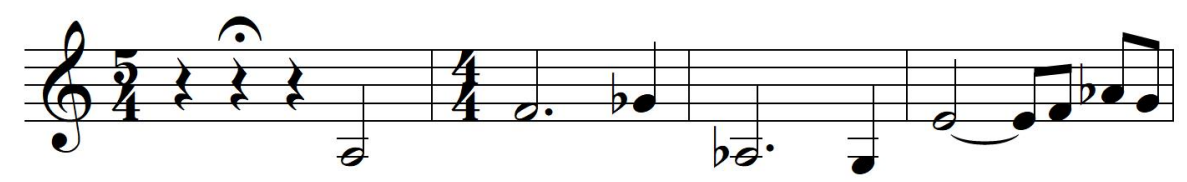

Figura 15: Motivo Tristão no Lento (Assai) da Sinfonia n. 8 de Heitor Villa-Lobos.

Redução. Compassos 2 a 5.

O motivo Tristão empregado por Villa-Lobos ${ }^{22}$ muito se assemelha ao de Wagner, por sua instabilidade cromática e pela semelhança da proporção das figurações rítmicas. A afinidade do timbre e da textura também auxiliam para essa associação, destacada pela similaridade na apresentação do tema, executado pelas violas sem acompanhamento.

Observamos no Lento (Assai) um procedimento de finalização conduzido pelo motivo Tristão no compasso 59, em ritenuto, conectando com a coda. A configuração intervalar do motivo Tristão villalobiano deste excerto é composta por uma sexta menor ascendente, terça menor descendente e segunda menor descendente. Mesmo que a relação intervalar não constitua a mesma, notamos o gesto melódico muito similar, especialmente na construção inicial, com o intervalo de sexta menor ascendente e, na construção final, com o intervalo de segunda menor descendente. Outro fator que corrobora para essa analogia está relacionado ao emprego dos timbres similares aos que Wagner utilizou na exposição do tema no Prelúdio de Tristão e Isolda, destacando a sonoridade dos violoncelos e do corne inglês. A figura 16 oferece o motivo Tristão empregado por Villa-Lobos na forma de gesto conclusivo.

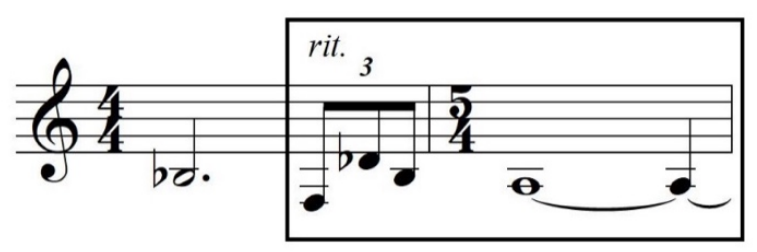

Figura 16: Finalização utilizando o motivo Tristão no Lento (Assai) da Sinfonia n. 8 de Heitor Villa-Lobos. Redução. Compassos 59 a 60.

O motivo Tristão empregado neste excerto por Villa-Lobos apresenta uma variação rítmica daquele exibido em boa parte do movimento, porém, como

\footnotetext{
${ }^{22}$ O motivo Tristão villalobiano é reapresentado cinco vezes no Lento (Assai).
} 
observamos, diversas características se mantêm. A figura 17 oferece um comparativo intervalar do motivo Tristão wagneriano e villalobiano.
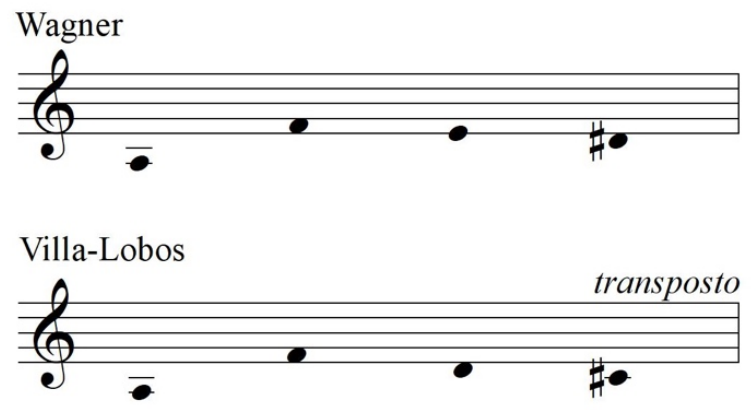

Figura 17: Comparativo do gesto melódico do motivo Tristão de Wagner e de VillaLobos.

\section{Finalização varèsiana}

Notamos a recorrência de outro procedimento conclusivo na música de Villa-Lobos, aparentemente inspirado por Edgard Varèse. Segundo Salles (2009), assim como Villa-Lobos, Vàrese também possuía interesse pelos atritos harmônicos e, consequentemente, pela sua sonoridade resultante (Salles 2009, p. 109). Villa-Lobos e Varèse se conheceram em Paris em 1927 e a amizade persistiu por muitos anos. Jardim (2005) questiona se a amizade e a convivência com Varèse acrescentaram algo à música de Villa-Lobos. $\mathrm{O}$ autor aponta o uso de algumas formações camerísticas inusitadas presentes em ambos compositores e estabelece um paralelo com a obra Intégrales (1923) de Varèse com os Choros $n$. 3 (1925) e Choros n. 7 (1924) de Villa-Lobos (Jardim 2005, p. 44).

Segundo Salles (2009), a Intégrales para onze sopros e percussão apresenta um fechamento seccional caracterizado pela presença de um acorde final, "marcado pelas ressonâncias e pelos sons resultantes de diversas dissonâncias agregadas" (Salles 2009, p. 145). O acorde final de Intégrales possui dez notas da escala cromática, deixando de fora apenas as notas Ré e Lá. Salles (2009) nomeia este tipo de finalização como cadência varèsiana, encontrada em diversas obras de Villa-Lobos, como os já mencionados Choros $n .3$ e Choros $n .7$ e nos Choros $n$. 8 (1925), Choros n. 10 (1926), Noneto (1923), Choros Bis (1928-1929), Rudepoema (1932) e no quarto movimento da Bachianas Brasileiras n. 8 (1944) (Salles 2009, p. 146). A figura 18 ilustra o acorde final de Intégrales. 


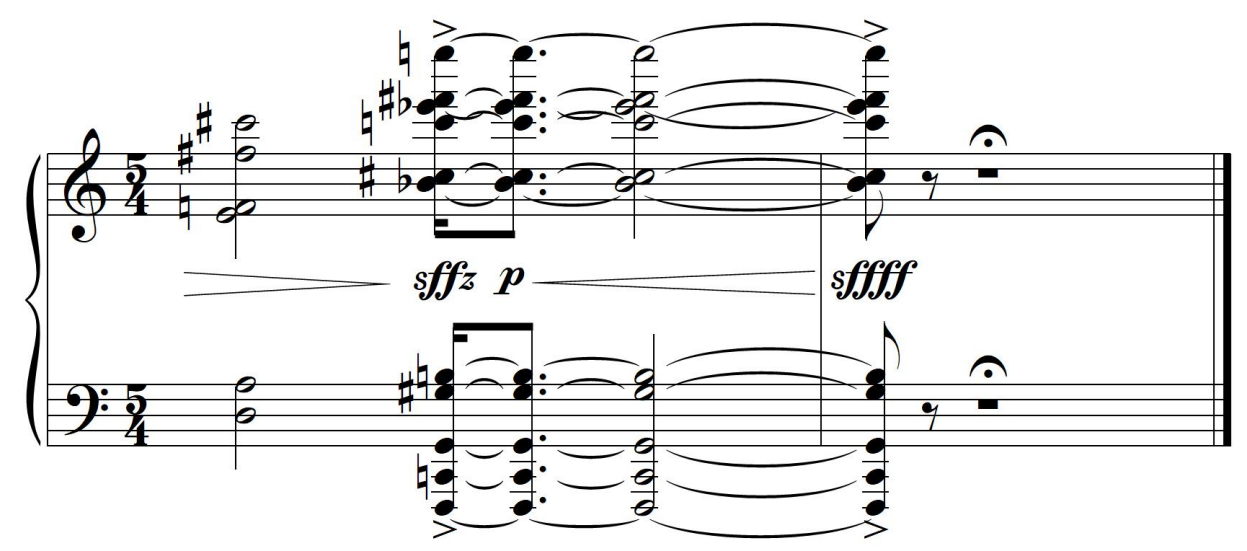

Figura 18: Acorde final de Intégrales de Edgard Varèse. Percussão omitida. Redução (Salles 2009, p. 145).

Em estudos posteriores, Salles (2018) observa a existência do acorde maior varèsiano, recorrente em dois momentos como acorde conclusivo nos movimentos dos dezessete quartetos de cordas villalobianos. Este acorde ( $\mathrm{FN}=5$ 22) é formado por uma superposição de uma tríade maior com uma tríade menor, disposta meio tom acima (exemplo: Dó maior e Dó\# menor). No acorde final de Intégrales, constatamos a superposição de dois acordes maiores varèsianos. Podemos extrair o acorde superposto de Mib maior com Mi menor e de Dó maior com Dó\# menor, conforme ilustra a figura 19.

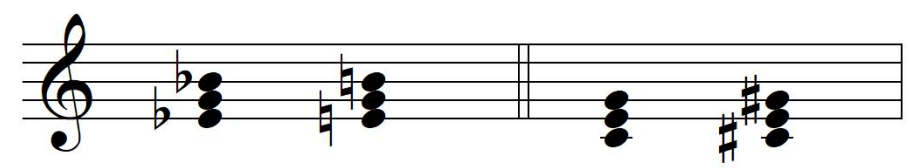

Figura 19: Acorde final de Intégrales de Edgard Varèse. Acordes maiores varèsianos. Redução.

Neste estudo, consideramos a finalização varèsiana caracterizada pela agregação de dissonâncias e pelas respectivas ressonâncias geradas, seja por meio de tríades ou tétrades com dissonâncias associadas, policordes, ou clusters, não carecendo, necessariamente, da presença do acorde maior varèsiano, sendo empregada por Villa-Lobos de forma muito similar ao procedimento de Varèse.

No segundo compasso do Lento (Assai) da Sinfonia n. 8, Villa-Lobos realizou uma superposição de notas distribuídas em diversos instrumentos e em vários registros. Este acorde é suspenso por meio de uma fermata, gerando assim ressonâncias dos intervalos dissonantes e consonantes executados simultaneamente, conforme ilustra a figura 20. 


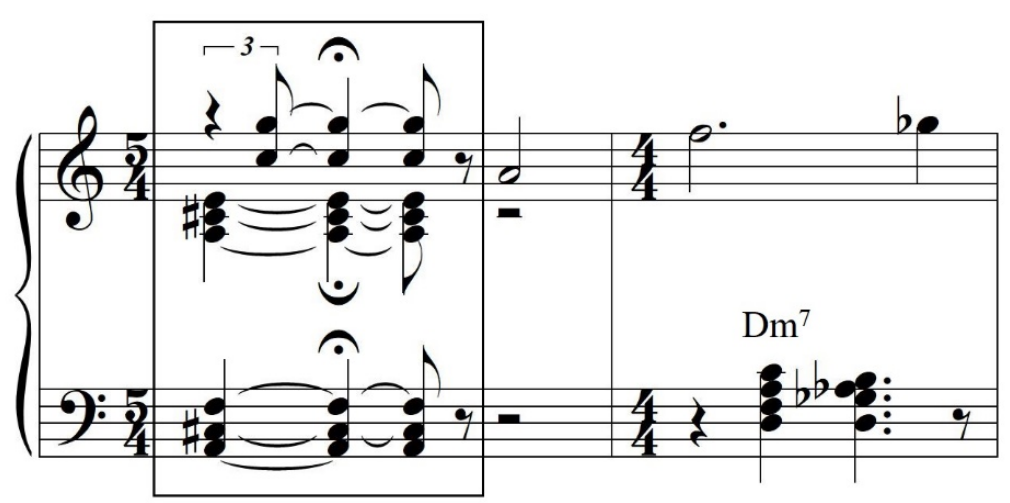

Figura 20: Finalização varèsiana no Lento (Assai) da Sinfonia n. 8 de Heitor Villa-Lobos. Redução. Compasso 2 e 3.

Neste excerto, podemos investigar três possibilidades de formações harmônicas. Considerando todas as notas apresentadas, temos o acorde FN=631. Podemos também considerar este acorde como um acorde de Fá aumentando com a sétima maior, em sua primeira inversão, agregando, posteriormente, as notas Dó e Sol, executadas pelas flautas transversais e celesta. Outra possibilidade de classificação deste acorde consiste na sobreposição dos acordes de Lá maior com sétima menor e Lá menor com sétima menor, ambos com a sexta adicionada. Dentre as três opções mencionadas, esta última aparenta ser a mais assertiva. Neste acorde, a função de dominante é caracterizada pelo pedal na nota Dó\# que resolve na nota Ré, assim como no movimento da nota Lá, ou do acorde de Lá maior com sétima menor, que direciona sua resolução para o acorde de Ré menor com sétima menor no compasso 3.

No último movimento, o Allegro (Justo), na seção do Piu Mosso, constatamos a presença de um acorde com características conclusivas, similar ao abordado anteriormente. Se considerarmos todas as notas oferecidas na construção deste acorde, obtemos o acorde $\mathrm{FN}=8-27$. É interessante observar a ambiguidade empregada nos acordes villalobianos. A partir das notas exibidas, podemos verificar a possibilidade de construção de diversas tétrades. Se considerarmos a nota Dó como uma apojatura para a nota Ré, as notas restantes do acorde são: Mi, Sol\#, Si, Fá, Sib, Ré, e Sol. A título de curiosidade, com essas notas podemos gerar as seguintes tétrades: Mi maior com sétima menor; $\mathrm{Mi}$ menor com sétima menor; Mi meio diminuto; Sol maior com sétima menor; Sol menor com sétima menor; Sol sustenido diminuto; e Si bemol maior com sétima menor, construído de forma enarmônica. Lembrando que a nota Dó foi considerada como uma apojatura, não sendo contemplada nessas construções. 
MUSICA THEORICA Revista da Associação Brasileira de Teoria e Análise Musical 2020, v. 5, n. 2, p. 226-258 - Journal of the Brazilian Society for Music

Caso ela fosse incluída, as possibilidades de acordes aumentariam consideravelmente. Entretanto, em meio a essas ressonâncias, observamos um movimento cadencial realizado pela nota Ré nas trompas. A nota Ré funciona como uma dominante do tema principal a ser exposto na nota Sol, sobreposta pela tríade de Sol maior oferecida pelos trombones, com a sobreposição de um ostinato em quartas sobrepostas, apresentado pelas madeiras, conforme ilustra a figura 21. Villa-Lobos utilizou este tipo de procedimento de justaposição de consonâncias e dissonâncias a fim de aludir aos movimentos tonais tradicionais, como o arquétipo da cadência perfeita.

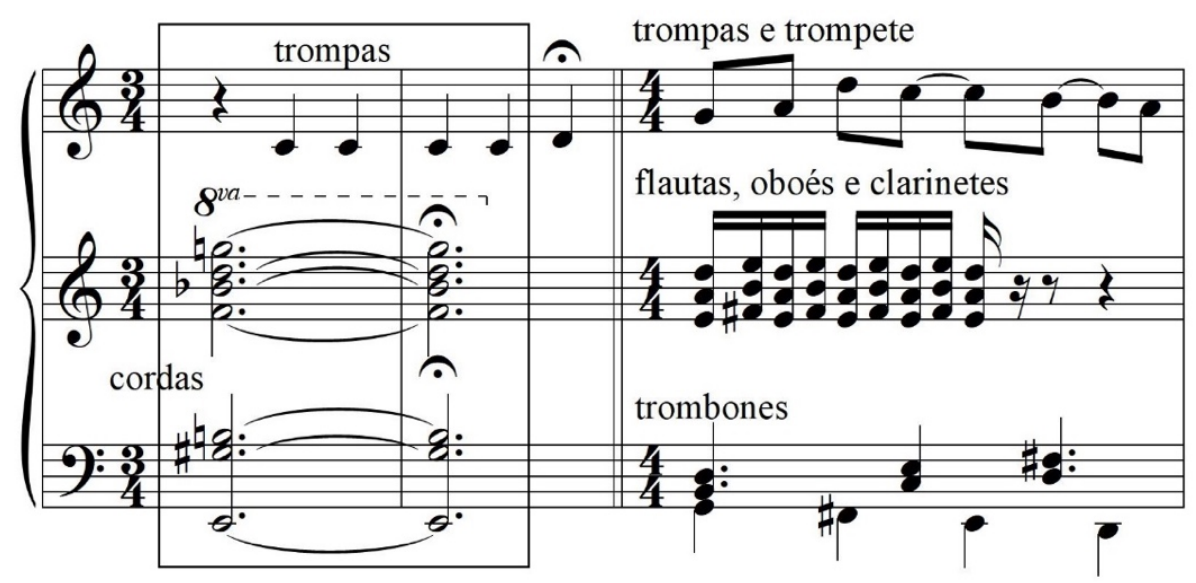

Figura 21: Finalização varèsiana no Piu Mosso do Allegro (Justo) da Sinfonia n. 8 de Heitor Villa-Lobos. Redução. Compassos 137 a 139.
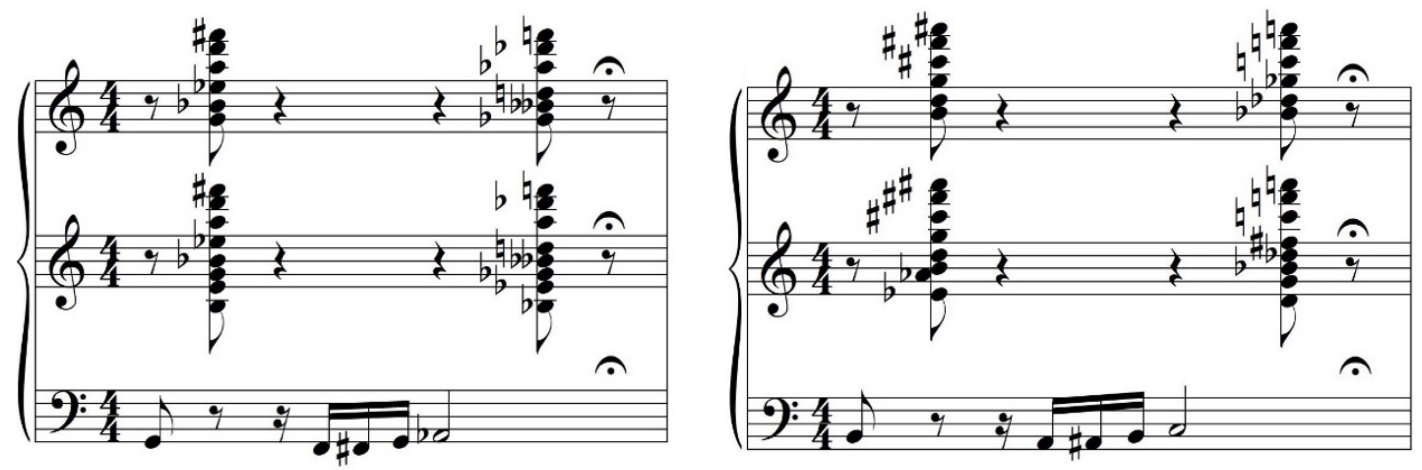

Figura 22: Finalizações varèsianas no Allegretto Scherzando da Sinfonia $n .8$ de Heitor Villa-Lobos. Redução. Compasso 13 e 133.

Nos compassos 13 e 133 do Allegretto Scherzando, notamos outro exemplo da justaposição de consonâncias e dissonâncias. Em ambos os casos, a finalização ocorre de forma suspensiva, a fim de realizar a conexão com o tema principal do movimento. O possível acorde empregado por Villa-Lobos neste excerto é o 
$\mathrm{FN}=8-20$, que pode ser associado com a sobreposição de alguns tipos de tríades e/ou tétrades, no qual podemos construir, no primeiro tempo do compasso, por exemplo, a tríade de Mib maior sobreposta com a tríade de Ré maior nas madeiras, ou mesmo uma tríade ambígua nos segundos violinos, podendo ser considerada um Mi menor ou um Mi diminuto. Villa-Lobos emprega dois acordes $\mathrm{FN}=8-20$ no compasso, de forma cromática descendente, com a finalidade de reduzir as sonoridades quartais apresentadas nos compassos anteriores. A figura 22 ilustra a ocorrência desta finalização, que é associada ao gesto conclusivo varèsiano, ocorrendo no compasso 13 e transposto, posteriormente, uma terça maior acima no compasso 133.

\section{Finalização em quartas}

Os acordes construídos em intervalos de quartas são abundantemente empregados por Villa-Lobos. Além dos ostinatos em acordes quartais presentes nesta sinfonia, notamos alguns procedimentos conclusivos construídos por essa sobreposição de quartas. No compasso 144 do primeiro movimento, o Andante, este procedimento conclusivo em quartas pode ser investigado na conexão do Piu Mosso com o A Tempo $1^{\underline{o}}$. Construído de forma descendente por graus conjuntos, essa melodia paralela em quartas superpostas é apresentada em forma de modelo e sequência a partir do compasso 141, possuindo uma sobreposição de um movimento melódico ascendente, executado pelos instrumentos graves, caracterizando uma reflexão horizontal ${ }^{23}$. Apesar deste paralelismo quartal, um movimento diatônico conecta as duas seções. A última nota executada na escala ascendente de graus conjuntos é a nota Mi, dominante da nota Lá, presente no início do tema em sua terceira transformação. Uma nota pedal em Mi também é apresentada a partir do compasso 141 pelas trompas, reforçando essa função de dominante. A figura 23 elucida este excerto.

\footnotetext{
${ }^{23}$ Este tipo de simetria consiste na reflexão dos movimentos da voz superior na voz inferior, realizando movimentos contrários nas vozes.
} 


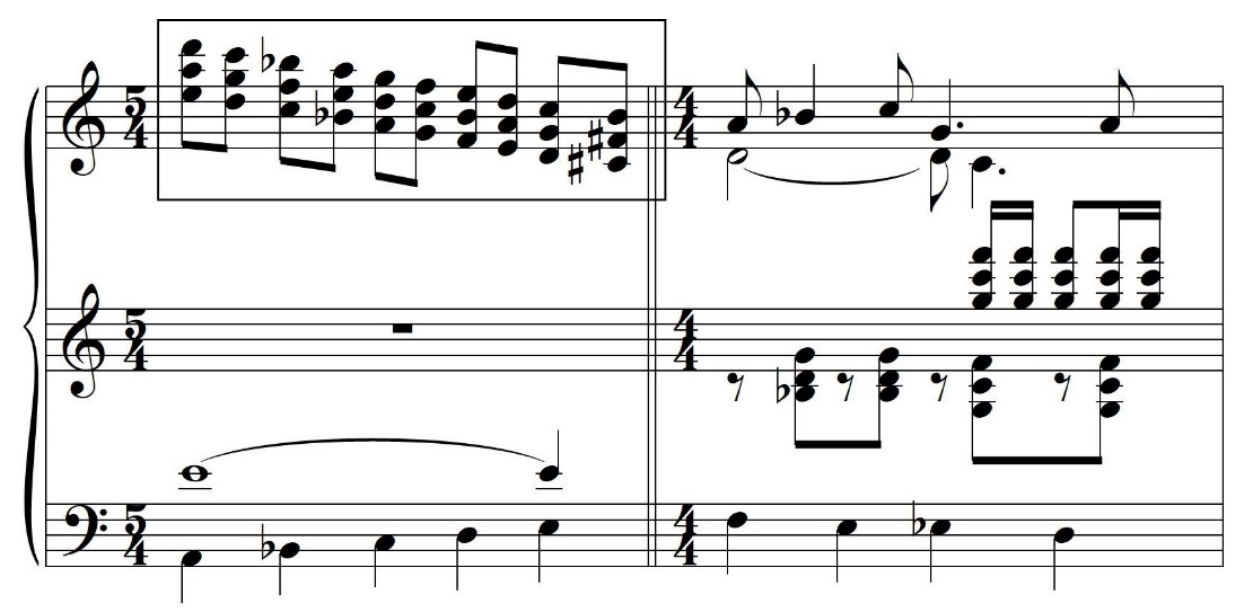

Figura 23: Finalização melódica em quartas no Andante da Sinfonia n. 8 de Heitor VillaLobos. Redução. Compasso 144 e 145.

No Allegro (Justo), investigamos procedimentos similares ao empregado no primeiro movimento. No compasso 66, o movimento em quartas justas realizado pelos primeiros e segundos violinos, violas e trompas é sobreposto pelo pedal em Mi, executado pelos violoncelos, contrabaixos e fagotes e pelo rufo dos tímpanos de forma crescente na nota $\mathrm{Sib}$, sendo um movimento de dominante a ser repousado na nota Mib do compasso 67, no início do tema de finalização da exposição. A figura 24 ilustra esse excerto.

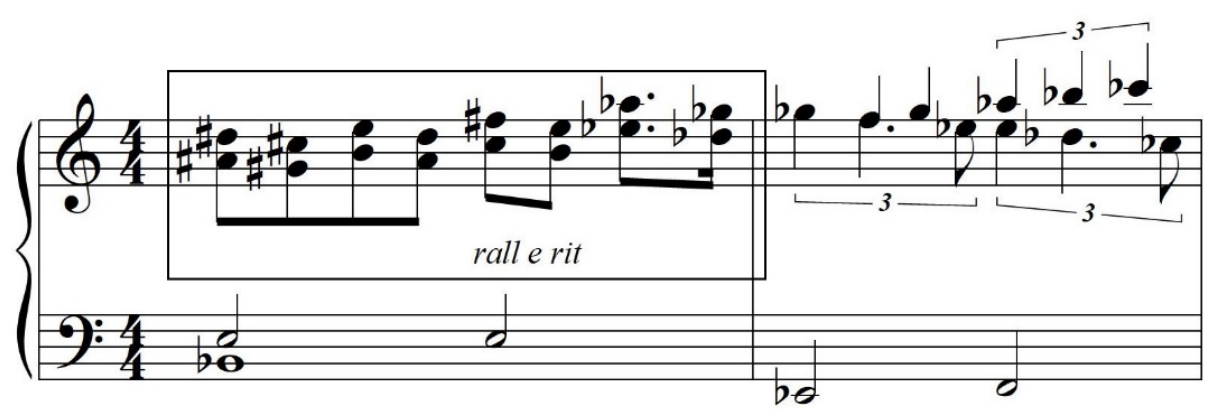

Figura 24: Finalização melódica em quartas no Allegro (Justo) da Sinfonia n. 8 de Heitor Villa-Lobos. Redução. Compasso 66 e 67.

Outro gesto conclusivo em quartas ocorre no compasso 74, conectando com a seção do Piu Mosso. Um movimento paralelo de quartas descendentes é oferecido pelas flautas, oboés, harpas, piano e celesta, sendo sobreposto pela notal pedal de Mib. Neste excerto também fica evidente a sobreposição de concepções cadenciais diatônicas desenvolvidas simultaneamente aos intervalos superpostos em quartas. A escala descendente pode ser interpretada como a escala de Mib menor natural. O pedal em Mib, ao que tudo indica, realiza um 
movimento harmônico de dominante e tônica, em que esse Mib é resolvido no compasso seguinte, na nota de Láb, conforme oferece a figura 25.

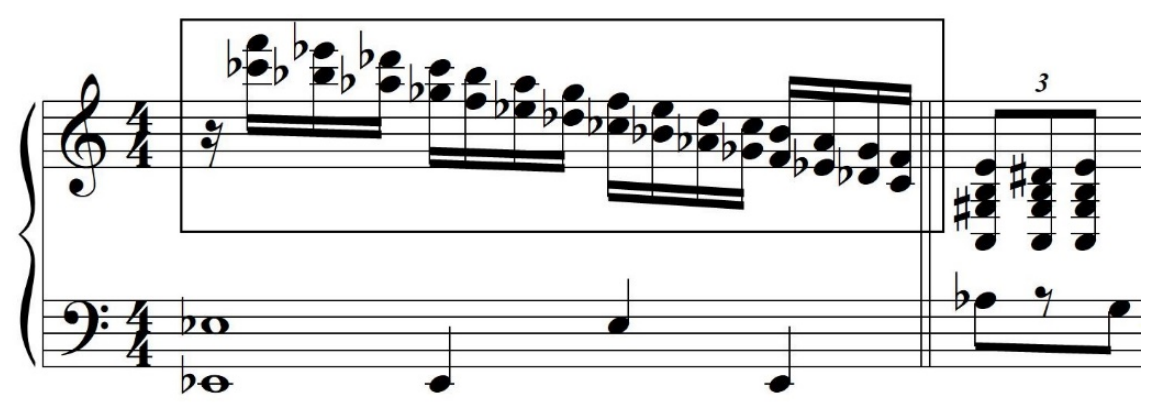

Figura 25: Finalização melódica em quartas no Allegro (Justo) da Sinfonia n. 8 de Heitor Villa-Lobos. Redução. Compasso 74 e 75.

\section{Finalização diatônica}

Um gesto tonal dissimulado também é observado no compasso 170 do quarto movimento, o Allegro (Justo), na conexão com a seção do Allegro Molto Animato. $\mathrm{O}$ acorde de Fá maior com sétima menor é apresentando nas cordas e trompas, oferecendo bordaduras inferiores nas notas Mib, Dó e Lá. Este acorde de dominante é resolvido no compasso 171, na nota Sib executada pelos violoncelos e contrabaixos, caracterizando assim uma finalização com concepções diatônicas, conforme a figura 26 apresenta.

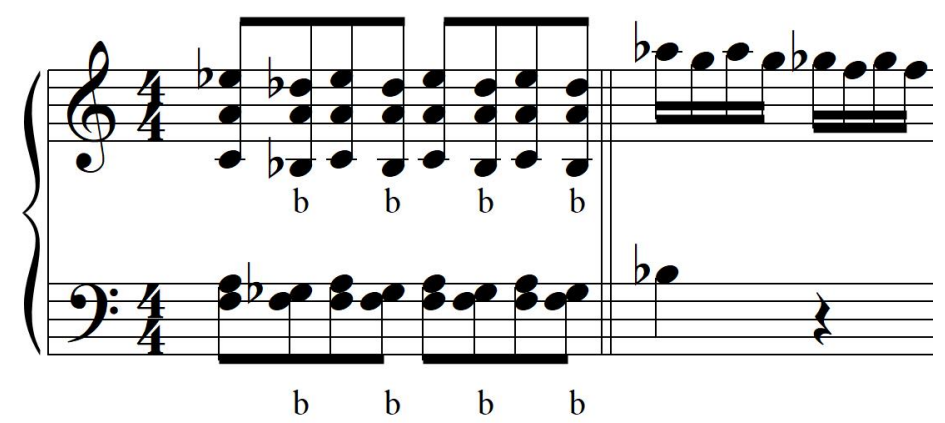

Figura 26: Finalização diatônica no Allegro (Justo) da Sinfonia n. 8 de Heitor Villa-Lobos. Redução. Compasso 170 e 171.

\section{Finalização cromática}

O Lento (Assai), segundo movimento da Sinfonia n. 8, é caracterizado pela alusão à música wagneriana e consequentemente ao cromatismo. No compasso 10, uma finalização cromática conecta o encerramento da exposição do primeiro 
tema para a reapresentação deste mesmo tema. Notamos, no compasso 9, o movimento cromático do acorde de Ré menor para o acorde de Mib menor. A nota Dób da melodia é tratada como uma apojatura que resolve no segundo tempo do compasso 10, na nota de Sib. O movimento cromático da harmonia conecta o fim da frase com a nova exposição do tema, retornando ao acorde de Ré menor, agora com a sétima menor, transformado, posteriormente, em um acorde de Ré diminuto. A nota Si é considerada enarmônica a nota Dób, caracterizando assim o acorde de Ré diminuto. A figura 27 ilustra esse excerto.

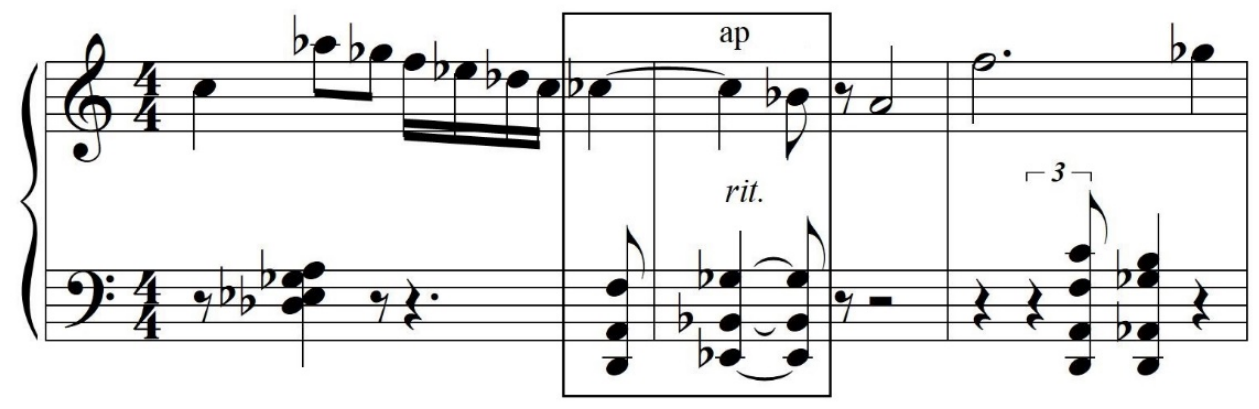

Figura 27: Finalização cromática no Lento (Assai) da Sinfonia n. 8 de Heitor Villa-Lobos. Redução. Compassos 9 a 11.

Outro exemplo peculiar de finalização cromática também ocorre neste movimento. Segundo Dudeque (2008), o emprego da tonalidade tradicional villalobiana é caracterizado, basicamente, por duas formas: seja por conceitos advindos da tonalidade moderna, observada no ciclo dos Choros, ou pela referência direta à música tonal e, consequentemente, à música de Bach. Em muitos momentos das Bachianas Brasileiras, progressões em sequências de quintas são recorrentes, aludindo ao procedimento típico bachiano. $\mathrm{O}$ autor ainda menciona outro ponto de similaridade da música bachiana com a música villalobiana, que está relacionado às texturas contrapontísticas e aos procedimentos rítmicos, ilustrados pelo autor na Ária (Cantilena) da Bachianas Brasileiras $n$. 5 (1938), que muito se assemelha ao contraponto tradicional bachiano (Dudeque 2008, p. 150). Tal alusão aos procedimentos bachianos pode ser investigada nos momentos finais do segundo movimento da Sinfonia n. 8, podendo estar relacionado com uma autocitação ou reaproveitamento de material advindo da Ária (Cantilena), da Bachianas Brasileiras n. $5^{24}$.

\footnotetext{
${ }^{24}$ Essa autocitação é investigada na tese Intertextualidade na Sinfonia n. 8 (1950) de Heitor Villa-Lobos (Pupia 2021, p. 128).
} 
Nos compassos 58 e 59 do Lento (Assai), Villa-Lobos ofereceu um gesto conclusivo inspirado na textura contrapontística bachiana e, possivelmente, referindo-se à sua própria obra. Este excerto é executado pelos contrabaixos em pizzicatos e pelos fagotes. No encerramento deste contraponto, notamos um movimento realizado por graus conjuntos da nota Solb para a nota Lá, que é apresentada pelo corne inglês e pelo clarinete. Este excerto é bastante curioso, pois sobrepõe duas ambientações distintas. Uma delas está baseada na possível alusão à música bachiana, demostrada pela possível referência textural contrapontística da Ária (Cantilena) da Bachianas Brasileiras n. 5. A outra ambientação advém da música wagneriana, presente em boa parte desse movimento, por meio da finalização em motivo Tristão, já mencionada, e pelo cromatismo. Como se trata da conexão de duas estéticas distintas, inicialmente caracterizada pela música bachiana e, posteriormente, pelo retorno das sonoridades wagnerianas, atribuímos a este tipo de gesto conclusivo um caráter cromático. A figura 28 ilustra esse excerto específico, ocorrente nos compassos 58 e 59, onde a nota Solb dos contrabaixos e fagotes se direciona para a nota Lá do corne inglês, violas e violoncelos, em um intervalo de segunda aumentada e a nota Sib, pertencente ao motivo Tristão, repousa cromaticamente na nota Lá.

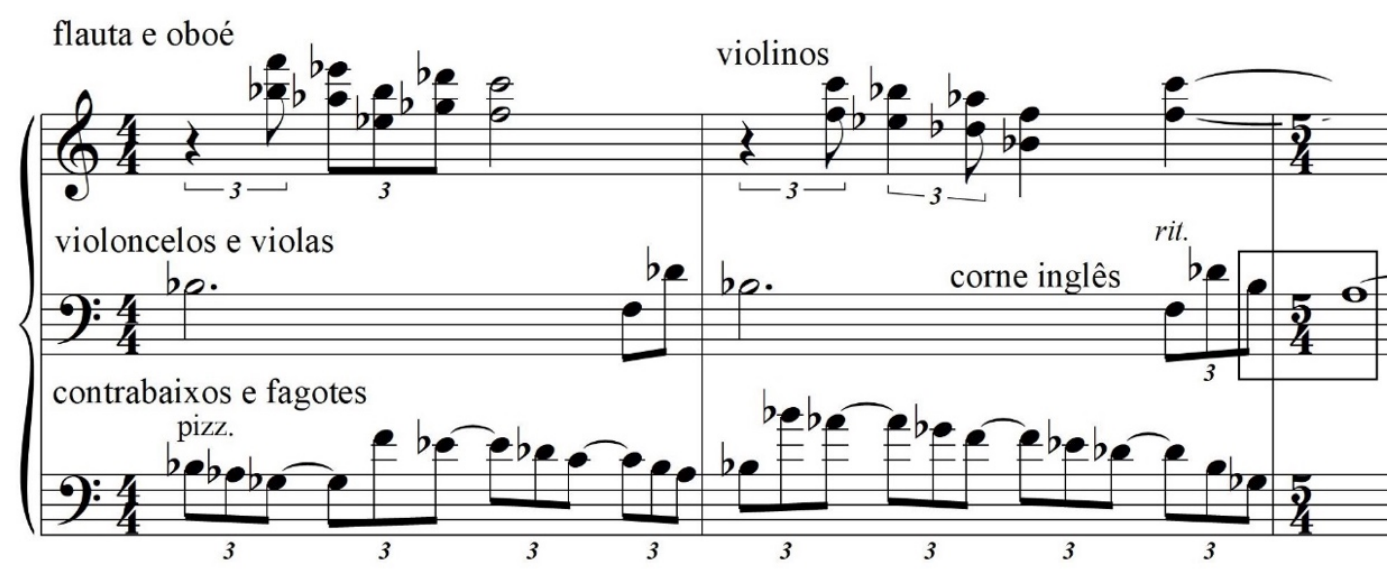

Figura 28: Finalização cromática no Lento (Assai) da Sinfonia n. 8 de Heitor Villa-Lobos. Redução. Compasso 58 e 59.

\section{Conclusão}

É de consenso que, posteriormente à primeira visita aos Estados Unidos, Villa-Lobos passou a compor essencialmente de acordo com as formas tradicionais, fazendo concessões ao público americano e às orquestras americanas. O compositor estava ciente da carga histórica que o arquétipo da 
sinfonia oferecia e, da mesma forma, estava ciente da valoração da música brasileira como material para composição de uma música original e que, conforme fosse adaptada e combinada com certas referências da música tradicional de concerto, supostamente poderia ser compreendida por todos os povos, podendo obter uma excelência universal.

Conforme discutimos, os gestos conclusivos empregados por Villa-Lobos aludem ao arquétipo cadencial tonal, à ideia de tensão e repouso, sendo uma concepção musical universal. Contudo, estes movimentos cadenciais são manipulados de forma bastante particular pelo compositor, muitas vezes inspirados nos procedimentos criativos de compositores precursores e contemporâneos. Endossando Fernandez (1945), Villa-Lobos foi um músico que estudou muito e acompanhou o desenvolvimento da música contemporânea, oferecendo sua própria contribuição, com soluções que, longe de serem meros acasos, são frutos de longas e pacientes observações (Fernandez 1945, p. 283-284).

Para concluir, buscamos em nossas investigações uma compreensão detalhada do processo cadencial utilizado por Villa-Lobos na Sinfonia n. 8, observando a coerência e a simetria harmônica adotada pelo compositor, apontando certas preferências de alguns recursos. A multiplicidade de influências e de releituras nesta oitava sinfonia é ampla e pode se alterar de acordo com o background do analista. Estas hipóteses levantadas, podem ser refutadas ou aprofundadas por colegas pesquisadores.

A tabela 2 ilustra os dez tipos de finalizações investigadas na Sinfonia $n .8$ e suas recorrências.

\begin{tabular}{lc}
\hline Tipo & Quantidade \\
\hline Oitavas (mônadas) & 4 \\
Díades & 2 \\
Pentatônico & 2 \\
Wagneriana & 1 \\
Acorde Tristão & 1 \\
Motivo Tristão & 1 \\
Varèsiana & 4 \\
Quartais & 3 \\
Diatônica & 1 \\
Cromática & 2 \\
\hline
\end{tabular}

Tabela 2: Tipos de finalizações ocorrentes na Sinfonia n. 8 de Heitor Villa-Lobos. 


\section{Referências}

1. Bloom, Harold. 1995. O cânone ocidental: os livros e a escola do tempo. Rio de Janeiro: Objetiva.

2. Brodbeck, David. 2017. Brahms: Sinfonia n. 1. Tradução: Alberto Cunha. São Paulo: Edusp.

3. Chailley, Jacques. 1962. Notes sur Tristan et Isolde (II Etude harmonique). L'éducation musicale, n. 88, p. 8-9.

4. Coelho de Souza, Rodolfo. 2017. O concerto para violão e a contribuição do pentatonismo na formação do estilo neoclássico de Villa-Lobos. In: Paulo de Tarso Salles e Norton Dudeque (orgs.). Villa-Lobos, um Compêndio: Novos Desafios Interpretativos. Curitiba: Editora da UFPR, p. 391-417.

5. Corrêa, Antenor Ferreira. 2012. Estendendo o conceito de cadência para o repertório pós-tonal. Per Musi, n. 26, p. 31-46.

6. Duarte, Roberto. Villa-Lobos errou? Subsídios para uma revisão musicológica em Villa-Lobos. Edição trilíngue. São Paulo: Algol, 2009.

7. Dudeque, Norton Eloy. 2008. Revisitando a "Ária (Cantilena)" da Bachianas Brasileiras n. 5 (1938) de Villa-Lobos. Música em perspectiva, vol. 1, n. 2, p. 131157.

8. __ 2016. Prométhée, Op. 21 de Leopoldo Miguez: considerações sobre o poema sinfônico, seu programa e a forma sonata. Revista Opus, vol. 22, n. 1, p. 9-34.

9. Farwell, Arthur. 1939. Nationalism in Music. In: Oscar Thompson, ed., The International Cyclopedia of Music and Musicians. New York: Dodd Mead \& Co., p. 1234-1239.

10. Fernandez, Oscar L. 1946. A contribuição harmônica de Villa-Lobos para a música brasileira. Boletim Latino Americano de Música, vol. 6, p. 283-300.

11. Forte, Allen. 1973. The Structure of Atonal Music. New Haven: Yale University Press.

12. Guérios, Paulo Renato. 2009. Heitor Villa-Lobos: o caminho sinuoso da predestinação. Curitiba: Edição do autor.

13. Hess, Carol A. 2013. Representing the good neighbor: music, difference, and the Pan American dream. New York: Oxford University Press.

14. Jardim, Gil. 2005. O Estilo Antropofágico de Heitor Villa-Lobos: Bach e Stravinsky na obra do compositor. São Paulo: Edição Philarmonia Brasileira. 
MUSICA THEORICA Revista da Associação Brasileira de Teoria e Análise Musical 2020, v. 5, n. 2, p. 226-258 - Journal of the Brazilian Society for Music

15. Kostka, Stefan M. 2006. Materials and techniques of twentieth-century music. 3 ed. New Jersey: Prentice Hall.

16. Museu Villa-Lobos. 2009. Villa-Lobos: sua obra. Rio de Janeiro: MinC; IBRAM; Museu Villa-Lobos, 2009.

17. Nattiez, Jean-Jacques. 1984. Verbete "Harmonia”. Enciclopédia Einaudi (v. 3). Lisboa: Imprensa Nacional, p. 245-271.

18. Piedade, Acácio Tadeu de Camargo. 2017a. Uma análise do prelúdio da Bachianas Brasileiras no 2 sob a perspectiva das tópicas, da retoricidade e da narratividade. In: Paulo de Tarso Salles e Norton Dudeque (orgs.). Villa-Lobos, um Compêndio: Novos Desafios Interpretativos. Curitiba: Editora da UFPR, p. 273-289.

19. _ _ 2017b. Planejamento Composicional como Narrativa? Uma Reflexão sobre Tópicas, Narratividade e Composição Musical a partir do Prelúdio da Bachianas No. 2 de Heitor Villa-Lobos. In: Ilza Nogueira e Guilherme Barros (eds.) Teoria e Análise Musical em Perspectiva Didática. Salvador: UFBA, p. 207219.

20. Pupia, Adailton Sergio. 2017. Intertextualidade na Bachianas Brasileiras n. 2 de Heitor Villa-Lobos. Dissertação de mestrado. Curitiba: Universidade Federal do Paraná.

21. __. 2021. Intertextualidade na Sinfonia n. 8 (1950) de Heitor Villa-Lobos. Tese de doutorado. Curitiba: Universidade Federal do Paraná.

22. Rodrigues, Pedro Henrique Belchior. 2019. O Maestro do Mundo: Heitor VillaLobos (1887-1959) e a diplomacia cultural brasileira. Tese de doutorado. Niterói: Universidade Federal Fluminense.

23. Salles, Paulo de Tarso. 2004. O acorde de Tristão em Villa-Lobos. Fórum do Centro de Linguagem Musical (v.1). São Paulo, p. 1-6.

24. __ 2009. Villa-Lobos: Processos Composicionais. Campinas: Editora da Unicamp.

25. _. 2018. Os quartetos de cordas de Villa-Lobos: forma e função. São Paulo: Edusp.

26. __ 2020. Uma narrativa musical do 'estado da alma' do compositor: a Sinfonia no 2 de Villa-Lobos. Debates UNIRIO, n. 24, p. 27-73.

27. Schoenberg, Arnold. 1911. Harmonielehre. Leipzig: Universal-edition.

28. __. 1948. Structural Functions of Harmony. New York: Norton.

29. Symphony N. 8. 2017. Intérprete: Orquestra Sinfônica do Estado de São Paulo. Compositor: Heitor Villa-Lobos. Alemanha: Naxos. 
30. Varèse, Edgard. 1926. Intégrales. Partitura. New York: G. Ricordi \& Co.

31. Villa-Lobos, Heitor. 1948. Bachianas Brasileiras n. 4. Partitura. New York: Consolidated Music Publishers.

32. __. 1950. Sinfonia n. 8. Partitura (manuscrito). Rio de Janeiro: s.n.

33. __. 2020. Bachianas Brasileiras n. 5. Partitura. Edição de Daniel Balparda de Carvalho.

34. Wagner, Richard. 1860. Tristan und Isolde. Partitura. Leipzig: Breitkopf und Härtel. 